\title{
Article
}

\section{Cloning animals for tourism in the year 2070}

Wright, Daniel

Available at http://clok.uclan.ac.uk/21051/

Wright, Daniel ORCID: 0000-0001-9976-5799 (2017) Cloning animals for tourism in the year 2070. Futures. ISSN 0016-3287

It is advisable to refer to the publisher's version if you intend to cite from the work. http://dx.doi.org/10.1016/j.futures.2017.10.002

For more information about UCLan's research in this area go to http://www.uclan.ac.uk/researchgroups/ and search for < name of research Group>.

For information about Research generally at UCLan please go to http://www.uclan.ac.uk/research/

All outputs in CLoK are protected by Intellectual Property Rights law, including Copyright law. Copyright, IPR and Moral Rights for the works on this site are retained by the individual authors and/or other copyright owners. Terms and conditions for use of this material are defined in the policies page.

\section{CLoK}

Central Lancashire online Knowledge www.clok.uclan.ac.uk

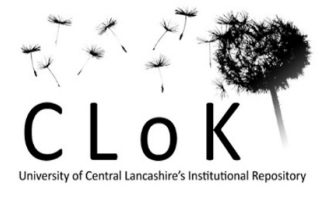


This is a pre-proof corrected manuscript, as accepted for publication, of an article published by Elsevier in Futures: Journal of Policy, Planning and Futures Studies Available online 14 October 2017, available online:

https://www.sciencedirect.com/science/article/pii/S0016328717302203

\section{PLEASE REFER TO THE FINAL VERSION FOR CITING PURPOSES}

Title: Cloning animals for tourism in the year 2070

\section{Author:}

Daniel William Mackenzie Wright

Address:

University of Central Lancashire,

Greenbank Building, Victoria Street,

Preston,

Lancashire,

United Kingdom

PR1 2HE

Email: Dwright3@uclan.ac.uk

Corresponding Author:

Daniel William Makenzie Wright 


\begin{abstract}
What role do animals have in a future tourism world - in the year 2070 ? Contemplating over meat and fish delights on restaurant menus, hunting for sport and leisure purposes, and the presence of safaris and zoos have aspects in common, significantly animals are central to their existence and tourists are key consumers. Importantly, these pastimes, social activates, and leisurely pursuits have their ancestral roots that pre-date modern society. Humans have long been associated with eating meat, hunting animals and holding animals in some form of captivity for recreation and education. Distinctively, this paper explores animal cloning and how it could support the extension and existence of these tourism pursuits in the future, focusing on the year 2070. The paper applies a scenario planning approach as its methodological approach to research. The study contributes innovative and original concepts to the future tourism landscape. Through rigorous analysis and discussions in the fields of animal cloning and its relationship with tourism and tourists in potential future settings, a gap in the future market is presented. This research paper presents three scenarios in which cloning could support future tourism markets, Food tourism 2070: A Japanese restaurant perspective, Sport Hunting and tourism 2070: Designated hunting reserves in South Africa; and Safari-zoo tourism 2070: Into the Wild, cloning for education \& conservation in the U.S.A. The paper offers interesting research for the futures field and tourism studies, offering scholars and industry with novel concepts for debating.
\end{abstract}




\section{Introduction}

"The allure of travel used to be the new, but as climate change continues to alter the environment, focus is shifting towards the nearly-extinct" (Ingham, 2015).

Are you the gastro tourist type when on holiday? Tasting and indulging in the local delicacies that are less accustomed to your place of permanent residence? Are you favourable to sport hunting and catching large game for purposes of pleasure and leisure, purposefully booking a holiday with the intent of visiting a destination to hunt wild game? Alternatively, are you more interested in seeing animals roam freely in natural habitats, more inclined to partake in a safari to witness wild animals interact with nature and other species? Nevertheless, what if our natural environments are depleted of species? What if in the coming years we begin to see large numbers of species go extinct, as numerous reports are suggesting? Does society have a solution to such extreme and potentially volatile mass depletion of species extinction? How comfortable are you with the idea of eating cloned meat? Would you pay to clone an animal so that you could be provided with the opportunity to hunt it? Would you allow specialists to clone animals for conservation and education and to set them free in natural habitats to learn and understand possible ways in which cloning could potentially be used as a method of saving species in risk of extinction, re-populating animal environments, and even bringing back animals that have become extinct? These questions and specifically, these three areas, cloning for food, sport hunting and animal preservation are not merely considered in a future context, where limited number is looking likely to become the norm. Finding answers can be complex, but society has at is knowledge a solution, one it has been exploring and developing for over a century, cloning.

Civilisation is faced with massive challenges within the natural environment and if reports have us believe, there is the potential that in the coming decades our natural world will look and be very different. With recognisable developments throughout the globe in the cloning field, there is much debate to its future practises and possibilities. The future uses of cloning is fascinating, especially from a tourism perspective. In as much, considering cloning from a supply and demand perspective to meet the needs and desires of future societies and their leisurely activities. This paper initially presents an insight into current developments in cloning before offering three scenarios, set in the year 2070, in which tourists could be engaging with cloned animals. The purpose and reasoning behind the selection of topics areas is clarified later on in more detail, however, Plato once said that "human behavior flows from three main sources: desire, emotion, and knowledge", states of being that flow through human history, and provoke both on an individual level and from a collective sense of being. The topics evoke a sense of realism, much to their past existence and presence in current human societies. The three scenarios in this research are entitled:

\section{Scenario one - Food Tourism: Luxury species dining \\ Scenario two - Cloning animals for sport hunting \\ Scenario three - Cloning animals for education \& conservation: Future safari zoo}

The purpose of this paper is to offer potential future scenarios, driven by evidence and factual knowledge, in which the act of cloning animals for tourism purposes could become a reality. This is significant, as the potential actuality of such scenarios could have significant impacts not only on the tourism industry, but more generally, it's broader, social, ethical considerations could have far reaching implications for future societies. Remarkably, this paper allows readers to conceive the prospect of tourism being potentially responsible for evolving and influencing societies association and accountability with animal cloning. The paper uses 
scenario planning as its methodological approach to research whilst taking a pragmatist position. The study offers innovative and original analysis and discussions in the fields of animal cloning and its relationship with tourism and tourists in potential future settings.

"We tend to approach the future tentatively, assuming it is unknowable, beyond the reach of our mental powers. Yet below the surface of daily events flows the endless progress of time in which everything in the universe evolves through an ordered sequence of states towards its final purpose" (Lee, 2012: 1).

\section{Research epistemology, method and approach}

"A future based upon prediction is founded upon certainty and a short time horizon whereas a science fiction future suspends all belief systems and looks for an explanation for how something could occur" (Bergman et al., 2010 in Yeoman et al., 2015: 3).

Science fiction aka Sci-fi is a broad genre, which often contains speculations based on current science and technology (Yeoman, 2012). Not to be mistaken with fantasy, sci-fi offers narratives, plots, stories in which its imaginary elements are conceivable - as belief is based on plausible explanation, routed in the dynamics of social and cultural understanding and claimed within the laws of nature. Scenario planning could be interpreted as science fiction. Importantly, Sci-fi is becoming more and more immersed into our everyday lives with technology bridging the gap between sci-fi reality and everyday life as highlighted by futurologist Lesley Gavin (Hartley, 2009).

"Future studies, or futurology, is the science, art and practice of postulating possible futures, or more basically, the study of the future seeks to understand what is likely to continue, what is likely to change, and what is novel. Part of the discipline thus seeks a systematic and pattern-based understanding of the past and present, and to determine the likelihood of future events and trends" (Yeoman et al., 2015: 25-26).

What are scenarios and scenario planning? A research method taken in this study, scenario planning is often a methodology applied in the futures field of study. There are different definitions, interpretations, and applications of scenario planning dependent on the perspective one agrees. From a more broad and historical sense, scenario analysis became a method for generating futures thinking and were seen as an effective presentation format. Alternatively, strategy was the focus for strategists and managers searching for tools and methods for complex issues (Yeoman et al., 2015). More recently, Walton (2008) considered scenarios within the paradigm of constructivist interpretation. A position somewhat undermined by the scenario approach that seeks 'plausible explanation'. Here, Fahey and Randall (1998: 9) stress the need that "plausible evidence should indicate that the projected narrative could take place (it is possible), demonstrate how it could take place (it is credible) and illustrate its implications for the organisations (it is relevant)." Heijden, Bradfield, Burt, Cairns, \& Wright (2002) suggest that "scenario planning is a process of predicting multiple, plausible and uncertain futures". According to Ramirez et al., (2015: 71) "scenarios are understood to be a small bespoke set of structured conceptual systems of equally plausible future context, often presented as narrative descriptions, manufactured for someone and for a purpose..." The importance of narrative writing as a method is also recognised by Lindgren \& Bandhold (2009), who identify the importance of telling a story to the reader, one with narratives, assisting ones understanding and interpretation.

"It is thought that foresight could be our most effective evolutionary tool for long-term survival and mastery of our environment. It is not just that foresight is a fundamental human skill. But 
we have amassed sufficient understanding of how the world works to produce real foreknowledge which anticipates future social conditions" (Lee, 2012: 2).

According to Bartunek, Rynes, \& Ireland (2006), authors should strive for research that produces learning, articles that will be read, debated and remembered. Research should aim to engage a wider audience, beyond the academic sphere. Ramirez, Mukherjee, Vezzoli \& Kramer (2015: 82) recognise the potential of scenario planning as a research methodology that can attract a wider audience, and suggest that "scenarios have moved on from an object of research by scholars into a research methodology scholars now use to produce interesting research', manifesting epistemological issues that the broader futures field has grappled with". 'Interesting research' refers to authors' adopting methodologies that stimulate and challenge new ideas (Alvesson \& Sandberg, 2011; Ramirez, et al., 2015). Researchers (Peterson, Cumming, \& Carpenter, 2003) state it is seen positively when presenting potential future realities. This research takes an exploratory approach to scenario planning. Taking a more contemporary approach, starting from the present, and then considering how potential consequences of present day are unfolded into the future. Thus, forward inferences are more common, taking a more regular way of thinking about the future (Jungermann, 1985, also see Bunn \& Salo, 1993) where past and current trends are more parallel throughout time. The scenarios presented in this research are of a descriptive nature, in contrast to normative scenarios. Normative scenarios present the user's own interests and desirability, whilst descriptive scenarios take a trend analysis approach, without offering personal desirability (Ducot and Lubben, 1980). The extrapolation approach can also be aligned with the current study, where the researcher considers the extension of past and current trends over time and considers them in a future context (Thompson, 1979). These conceptual research methods all lend themselves and support a trend analysis approach when exploring and presenting future scenarios.

As noted by Lee (2012) future research is commonly seen as a multi-disciplinary approach, as it draws on data and ideas from a range of sciences. Lee (2012) recognises the difficulty in exploring the future often lays in effectively integrating knowledge from a variety of disciplines from the social and hard sciences when trying to present a comprehensive foundation for predicting complex social futures. However, this should not be seen as an "insurmountable obstacle" (Lee, 2012; 2). The epistemological approach taken in this research is aligned with pragmatism. Pragmatism emphasises that any theory that proves itself more successful in predicting and controlling our world than its rivals can be considered to be nearer the truth. Pragmatism, rejects the philosophy of formalism and or the belief that there is one scientific method or framework whose practice would result in indisputable knowledge. Arguably, a complex and difficult assumption to make when exploring 'potential' futures. Pragmatism is commonly applied by social scientists who apply mixed methods, multiple methods, and or serial methods to research. Thus, a pragmatic approach embraces plurality of methods and multiple philosophies (Maxcy, 2003). Pragmatism is often viewed as the philosophical partner for the mixed methods approach to research. The pragmatic approach offers a set of assumptions about knowledge and enquiry that is seen as the foundation to mixed methods. In so doing, it differentiates itself from the purely quantitative approaches, often aligned with the (post)positivism philosophy and the qualitative approaches based on the interpretivist or constructivist research philosophies (Johnson \& Onwuegbuzie, 2004; Maxcy, 2003; Rallis \& Rossman, 2003). Pragmatism can provide a synthesis of approaches, allowing researcher to locate common ground between different forms of research philosophies (e.g. Datta, 1994; Maxcy, 2003; Tashakkori \& Teddlie, 1998, 2003). Authors (Tashakkori \& Creswell, 2007; Johnson, Onwuegbuzie, \& Turner, 2007) have also recognised how pragmatism offers a 'third alternative' for using mixed methods approaches, often applied, when neither quantitative nor qualitative research alone is deemed sufficient to gather findings for the particular type of research. This research through a pragmatist approach embraces different views from secondary data sources, both qualitative and quantitative research, from constructivism to positivism position, drawing on academic knowledge, scientific studies, industry perspectives, 
political understanding, and other newsworthy and reliable sources. Therefore, ensuring balanced ideas and perspectives are fused into the scenarios and the justification of them. Ultimately, the future is open to examination, and through tested methods of scenario planning and narrative writing, this paper proposes future scenarios based on past and current knowledge, ideas and debates.

\section{Species preservation: troubled times}

"Human behaviour continues to drive the decline of wildlife populations globally, with particular impact on freshwater habitats. Importantly, however, these are declines - they are not yet extinctions - and this should be a wake-up call to marshal efforts to promote the recovery of these populations" (Norris, 2016).

Our environments are populated with a mixture of species that are dependent on many factors for survival, from food resources, climate and migration patterns, and, humans rely on animals for many purposes, significantly as a source of food. There continues to be scientific coverage reporting the depletion of our natural environment and the impacts this is having on species. A Living Planet Report (2016) stresses that unless we act now, wildlife populations will decline by $67 \%$ by 2020 . Another reports claims that for the first time since the dinosaurs (65 million years ago) humanity is facing a global mass extinction of wildlife. Consequently, due to our misuse of natural resources humans are threatening natural habitats, and subsequently pushing species to the brink of extinction (Barrett, 2016). Other reports highlight how food production to meet the needs of an expanding human population is a key driver of activities such as, overfishing, hunting and destruction of habitats, all of which are causing biodiversity loss (Zoological Society of London, 2016). According to director General of WWF international, Marco Lambertini, "Across land, freshwater and the oceans, human activities are forcing species populations and natural systems to the edge. We have the tools to fix this problem and we need to start using them if we are serious about our own survival and prosperity" (Carrington, 2014).

A paper published in Science Advances by Ceballos, Ehrlich, Barnosky, Garcia, Pringle \& Palmer (2015), the researchers warn that Earth is entering the sixth mass extinction. If humans do not act now, in the next 50 years we will be living in a completely different world, a world that will challenge humanity like never before. Scientists have acknowledged the birth of the Industrial Revolution as a tipping point for increased species extinction on land. With increased demand for lumber and expanding farmlands and factories, the effect meant levelling forest habitats and consequently pollution and other factors eradicated various animals (CareyStanford, 2015). Now two hundred years later, the industrialization of the fishing industry has left our oceanic species encountering similar devastating impacts. With a research publication in the journal Science suggesting that ocean acidification is a serious issue. The research highlighted the continued neglect of our oceans would threaten the entire marine biosphere, also affecting land-dwelling creatures who are ocean dependent (Merchant, 2015).

The International Union for Conservation of Nature (IUCN) Global Species Programme (2017) offer insightful information on species vulnerability, with recent reports including the following: On the 04 May 2017 IUCN rings alarm bells for corals in the Mediterranean: Over 13\% of anthozoan species in the Mediterranean Sea - which include corals and related species - are threatened with extinction. Another report on 08 March 2017 stressed that climate change is hitting species hard - we should keep an eye on the most vulnerable. It found that almost half $(47 \%)$ of threatened land mammals and almost a quarter $(23.4 \%)$ of all threatened birds may 
already have been negatively impacted by climate change. These findings are sobering, especially given that the impacts of climate change are not likely to abate, nor are species likely to adapt to them in realistic ecological time scales. For further details on animal extinction visit the IUCN website who state that their role has been "assessing the conservation status of species, subspecies, varieties, and even selected subpopulations on a global scale for the past 50 years in order to highlight taxa threatened with extinction, and thereby promote their conservation. Although today we are operating in a very different political, economic, social and ecological world from that when the first IUCN Red Data Book was produced, the IUCN Global Species Programme, working with the Species Survival Commission and many partners, remains firmly committed to providing the world with the most objective, scientificallybased information on the current status of globally threatened biodiversity. The plants, fungi and animals assessed for The IUCN Red List are the bearers of genetic diversity and the building blocks of ecosystems, and information on their conservation status and distribution provides the foundation for making informed decisions about conserving biodiversity from local to global levels" (The IUCN Red List of Threatened Species, 2017). Numerous reports on animal extrication could have been selected to highlight the significance of the issue, far too many to offer a full coverage in this section. However, for this research, the above offers sufficient evidence that the potential issues facing our natural wildlife are alarming. Animal extinction is often a result of habitat change and destruction and the above sources are highlighting the significant changes our environments might be faced with in next few decades, and the threat of species extinction.

\section{A brief history of cloning}

"Lost in the midst of all the buzz about cloning is the fact that cloning is nothing new: its rich scientific history spans more than 100 years" (Learn Genetics, 2017).

Any discussion about cloning should consider definitions. Cloning often occurs at three different levels, DNA, the single cell, or the whole organism, as can be seen in table 1. Ethical attention and or debates are often focused upon cloning when the genetic copying of a whole organism is in question. The cloning of non-mammals has transpired for many years in research contexts with the cloning of the first mammal, Dolly the sheep, surprising many in the scientific community and beyond. What followed from this was the cloning of other species and more recently increased speculation and debate on the possibility of cloning humans.

Table 1: Introducing cloning

\footnotetext{
What is cloning?

The term cloning describes a number of different processes that can be used to produce genetically identical copies of a biological entity. The copied material, which has the same genetic makeup as the original, is referred to as a clone. Researchers have cloned a wide range of biological materials, including genes, cells, tissues and even entire organisms, such as a sheep.

Do clones ever occur naturally?

Yes. In nature, some plants and single-celled organisms, such as bacteria, produce genetically identical offspring through a process called asexual reproduction. In asexual reproduction, a new individual is generated from a copy of a single cell from the parent organism. Natural clones, also known as identical twins, occur in humans and other mammals. These twins are produced when a fertilized egg splits, creating two or more embryos that carry almost identical DNA. Identical twins have nearly the same genetic makeup as each other, but they are genetically different from either parent.
} 


\section{What are the types of artificial cloning?}

There are three different types of artificial cloning: gene cloning, reproductive cloning and therapeutic cloning. Gene cloning produces copies of genes or segments of DNA. Reproductive cloning produces copies of whole animals. Therapeutic cloning produces embryonic stem cells for experiments aimed at creating tissues to replace injured or diseased tissues. Gene cloning, also known as DNA cloning, is a very different process from reproductive and therapeutic cloning. Reproductive and therapeutic cloning share many of the same techniques, but are done for different purposes.

Source: National Human Genome Research Institute (2017)

This paper will not concern itself with human cloning. The focus is on animal cloning and its future potentiality from tourism supply and demand perspectives. Table 2 is a timeline offering a brief history and a list of examples of cloning from 1938 to 2013, with a greater focus on advances in animal cloning.

Table 2: A timeline of key cloning events to date

\begin{tabular}{|c|c|c|}
\hline Date & Focus & Bio \\
\hline 1885 & $\begin{array}{l}\text { First-ever } \\
\text { demonstration } \\
\text { of artificial } \\
\text { embryo twinning }\end{array}$ & $\begin{array}{l}\text { Sea urchin } \\
\text { Hans Adolf Edward Dreisch } \\
\text { The sea urchin is a relatively simple organism that is useful for studying } \\
\text { development. Dreisch showed that by merely shaking two-celled sea urchin } \\
\text { embryos, it was possible to separate the cells. Once separated, each cell grew } \\
\text { into a complete sea urchin. } \\
\text { This experiment showed that each cell in the early embryo has its own } \\
\text { complete set of genetic instructions and can grow into a full organism. }\end{array}$ \\
\hline 1902 & $\begin{array}{l}\text { Artificial embryo } \\
\text { twinning in a } \\
\text { vertebrate }\end{array}$ & $\begin{array}{l}\text { Salamander } \\
\text { Hans Spemann } \\
\text { Spemann's first challenge was to figure out how to split the two cells of an } \\
\text { embryo much stickier than sea urchin cells. Spemann fashioned a tiny noose } \\
\text { from a strand of baby hair and tightened it between two cells of a salamander } \\
\text { embryo until they separated. Each cell grew into an adult salamander. } \\
\text { Spemann also tried to divide more advanced salamander embryos using this } \\
\text { method, but he found that cells from these embryos weren't as successful at } \\
\text { developing into adult salamanders. } \\
\text { This experiment showed that embryos from a more-complex animal can also } \\
\text { be "twinned" to form multiple identical organisms - but only up to a certain } \\
\text { stage in development. }\end{array}$ \\
\hline 1928 & $\begin{array}{l}\text { The cell nucleus } \\
\text { controls } \\
\text { embryonic } \\
\text { development }\end{array}$ & $\begin{array}{l}\text { Salamander } \\
\text { Hans Spemann } \\
\text { Again using a strand of baby hair tied into a noose, Spemann temporarily } \\
\text { squeezed a fertilized salamander egg to push the nucleus to one side of the } \\
\text { cytoplasm. The egg divided into cells - but only on the side with the nucleus. } \\
\text { After four cell divisions, which made } 16 \text { cells, Spemann loosened the noose, } \\
\text { letting the nucleus from one of the cells slide back into the non-dividing side of } \\
\text { the egg. He used the noose to separate this "new" cell from the rest of the } \\
\text { embryo. The single cell grew into a new salamander embryo, as did the } \\
\text { remaining cells that were separated. } \\
\text { Essentially the first instance of nuclear transfer, this experiment showed that } \\
\text { the nucleus from an early embryonic cell directs the complete growth of a } \\
\text { salamander, effectively substituting for the nucleus in a fertilized egg. }\end{array}$ \\
\hline 1952 & $\begin{array}{l}\text { First successful } \\
\text { nuclear transfer }\end{array}$ & $\begin{array}{l}\text { Frog } \\
\text { Robert Briggs and Thomas King }\end{array}$ \\
\hline
\end{tabular}




\begin{tabular}{|c|c|c|}
\hline & & $\begin{array}{l}\text { An attempt to clone a Rana pipiens frog: Robert Briggs and Thomas King; the } \\
\text { scientists collect the nucleus from a frog egg cell with a pipette and replace it } \\
\text { with the nucleus taken from a cell of a frog embryo; the experiment is not } \\
\text { successful. }\end{array}$ \\
\hline 1958 & $\begin{array}{l}\text { Nuclear transfer } \\
\text { from a } \\
\text { differentiated } \\
\text { cell }\end{array}$ & $\begin{array}{l}\text { Frog } \\
\text { John Gurdon } \\
\text { Gurdon transplanted the nucleus of a tadpole intestinal cell into an enucleated } \\
\text { frog egg. In this way, he created tadpoles that were genetically identical to the } \\
\text { one from which the intestinal cell was taken. } \\
\text { This experiment showed that, despite previous failures, nuclei from somatic } \\
\text { cells in a fully developed animal could be used for cloning. Importantly, it } \\
\text { suggested that cells retain all of their genetic material even as they divide and } \\
\text { differentiate (although some wondered if the donor DNA came from a stem } \\
\text { cell, which can differentiate into multiple types of cells). }\end{array}$ \\
\hline 1984 & $\begin{array}{l}\text { First mammal } \\
\text { created by } \\
\text { nuclear transfer }\end{array}$ & $\begin{array}{l}\text { Sheep } \\
\text { Steen Willadsen } \\
\text { Willadsen used a chemical process to separated one cell from an 8-cell lamb } \\
\text { embryo. The he used a small electrical shock to fuse it to an enucleated egg } \\
\text { cell. As luck would have it, the new cell started dividing. } \\
\text { By this time, in vitro fertilization techniques had been developed, and they had } \\
\text { been used successfully to help couples have babies. So after a few days, } \\
\text { Willadsen placed the lamb embryos into the womb of surrogate mother sheep. } \\
\text { The result was the birth of three live lambs. } \\
\text { This experiment showed that it was possible to clone a mammal by nuclear } \\
\text { transfer-and that the clone could fully develop. Even though the donor nuclei } \\
\text { came from early embryonic cells, the experiment was considered a great } \\
\text { success. }\end{array}$ \\
\hline 1987 & $\begin{array}{l}\text { Nuclear transfer } \\
\text { from embryonic } \\
\text { cell }\end{array}$ & $\begin{array}{l}\text { Cow } \\
\text { Neal First, Randal Prather, and Willard Eyestone } \\
\text { Using methods very similar to those used by Willadsen on sheep, First, } \\
\text { Prather, and Eyestone produced two cloned calves. Their names were Fusion } \\
\text { and Copy. } \\
\text { This experiment added cows to the list of mammals that could be cloned by } \\
\text { nuclear transfer. Still, mammalian cloning was limited to using embryonic cells } \\
\text { as nuclear donors. Cloning using nuclei from differentiated adult somatic cells } \\
\text { still wasn't thought possible. }\end{array}$ \\
\hline 1996 & $\begin{array}{l}\text { Nuclear transfer } \\
\text { from laboratory } \\
\text { cells }\end{array}$ & $\begin{array}{l}\text { Sheep } \\
\text { lan Wilmut and Keith Campbell } \\
\text { All previous cloning experiments used donor nuclei from cells in early } \\
\text { embryos. In this experiment, the donor nuclei came from a slightly different } \\
\text { source: cultured sheep cells, which were kept alive in the laboratory. } \\
\text { Wilmut and Campbell transferred the nuclei from cultured cells into enucleated } \\
\text { sheep egg cells. The lambs born from this procedure were named Megan and } \\
\text { Morag. } \\
\text { This experiment showed that cultured cells can supply donor nuclei for cloning } \\
\text { by nuclear transfer. Because scientists had already learned how to transfer } \\
\text { genes into cultured cells, this experiment showed that it might be possible to } \\
\text { use such modified cells to create transgenic animals-such as cows that could } \\
\text { make insulin for diabetics in their milk. }\end{array}$ \\
\hline 1997 & $\begin{array}{l}\text { First primate } \\
\text { created by } \\
\text { embryonic cell } \\
\text { nuclear transfer }\end{array}$ & $\begin{array}{l}\text { Rhesus monkey } \\
\text { Li Meng, John Ely, Richard Stouffer, and Don Wolf }\end{array}$ \\
\hline
\end{tabular}




\begin{tabular}{|c|c|c|}
\hline & & $\begin{array}{l}\text { Primates are good models for studying human disorders. Cloning identical } \\
\text { primates would decrease the genetic variation of research animals, and } \\
\text { therefore the number of animals need in research studies. } \\
\text { Similar to previous cloning experiments, Wolf's team of scientists fused early- } \\
\text { stage embryonic cells with enucleated monkey egg cells using a small } \\
\text { electrical shock. The resulting embryos were then implanted into surrogate } \\
\text { mothers. Out of } 29 \text { cloned embryos, two monkeys were born. One was a } \\
\text { female named Neti, and the other was a male named Ditto. } \\
\text { This experiment showed that primates, humans' closest relatives, can be } \\
\text { cloned. }\end{array}$ \\
\hline 1997 & $\begin{array}{l}\text { Nuclear transfer } \\
\text { from genetically } \\
\text { engineered } \\
\text { laboratory cells }\end{array}$ & $\begin{array}{l}\text { Sheep } \\
\text { Angelika Schnieke, Keith Campbell, lan Wilmut } \\
\text { This experiment was an exciting combination of findings from earlier work. } \\
\text { Campbell and Wilmut had already created a clone using the nucleus of a } \\
\text { cultured cell. This time, the researchers introduced the human Factor IX } \\
\text { ("factor nine") gene into the genome of sheep skin cells grown in a laboratory } \\
\text { dish. Factor IX codes for a protein that helps blood clot, and it's used to treat } \\
\text { hemophilia, a genetic disorder where blood doesn't form proper clots. } \\
\text { To create the transgenic sheep, the scientists performed nuclear transfer using } \\
\text { donor DNA from the cultured transgenic cells. The result was Polly, a sheep } \\
\text { that produced Factor IX protein in her milk. } \\
\text { This experiment showed that sheep could be engineered to make therapeutic } \\
\text { and other useful proteins in their milk, highlighting the potential medical and } \\
\text { commercial uses for cloning. }\end{array}$ \\
\hline $\begin{array}{l}1998- \\
1999\end{array}$ & $\begin{array}{l}\text { More mammals } \\
\text { cloned by } \\
\text { somatic cell } \\
\text { nuclear transfer }\end{array}$ & $\begin{array}{l}\text { Mice, cows, and goats } \\
\text { Multiple groups } \\
\text { After the successes leading up to Dolly and Polly, other scientists wanted to } \\
\text { see if similar techniques could be used to clone other mammalian species. } \\
\text { Before long, several more animals had been successfully cloned. Among them } \\
\text { were transgenic animals, clones made from fetal and adult cells, and a male } \\
\text { mouse; all previous clones had been female. }\end{array}$ \\
\hline 2001 & $\begin{array}{l}\text { Endangered } \\
\text { animals cloned } \\
\text { by somatic cell } \\
\text { nuclear transfer }\end{array}$ & $\begin{array}{l}\text { Gaur and Mouflon } \\
\text { Multiple groups } \\
\text { As the list of successfully cloned animals grew, scientists began to explore } \\
\text { cloning as a way to create animals belonging to endangered or extinct species. } \\
\text { A challenge to cloning endangered and extinct species is finding closely } \\
\text { related animals to serve as egg donors and surrogates. The gaur and mouflon } \\
\text { were chosen in part because they are close relatives of domestic cattle and } \\
\text { sheep, respectively. } \\
\text { In 2009, using goast as egg donors and surrogates, another group of } \\
\text { researchers cloned the first extinct animal, a Spanish mountain goat called the } \\
\text { bucardo. Sadly, the one kid that survived gestation died soon after birth due } \\
\text { to a lung defect. }\end{array}$ \\
\hline 2007 & $\begin{array}{l}\text { Primate } \\
\text { embryonic stem } \\
\text { cells created by } \\
\text { somatic cell } \\
\text { nuclear transfer }\end{array}$ & $\begin{array}{l}\text { Rhesus monkey } \\
\text { Shoukhrat Mitalipov and colleagues } \\
\text { Researchers took a cell from an adult monkey and fused it with an enucleated } \\
\text { egg cell. The embryo was allowed to develop for a time, then its cells were } \\
\text { grown in a culture dish. These cells, because they can differentiate to form any } \\
\text { cell type, are called embryonic stem cells. } \\
\text { This experiment showed that nuclear transfer in a primate, which researchers } \\
\text { had tried for years without success, was possible. It opened the door to the } \\
\text { possibility of human therapeutic cloning: creating individual-specific stem cells } \\
\text { that could be used to treat or study diseases. }\end{array}$ \\
\hline
\end{tabular}




\begin{tabular}{|l|l|l|}
\hline 2013 & $\begin{array}{l}\text { Human } \\
\text { embryonic stem } \\
\text { cells created by } \\
\text { somatic cell } \\
\text { nuclear transfer }\end{array}$ & $\begin{array}{l}\text { Human } \\
\text { Shoukhrat Mitalipov and colleagues } \\
\text { Overcoming decades of technical challenges, Mitalipov and colleagues were } \\
\text { the first to use somatic cell nuclear transfer to create a human embryo that } \\
\text { could be used as a source of embryonic stem cells. The resulting stem cell } \\
\text { lines were specific to the patient they came from, a baby with a rare genetic } \\
\text { disorder. }\end{array}$ \\
$\begin{array}{l}\text { In this experiment, researchers took a skin cell from the patient and fused it } \\
\text { with a donated egg cell. Key to the success of the experiment were } \\
\text { modifications to the culture liquid in which the procedure was done and to the } \\
\text { series of electrical pulses used to stimulate the egg to begin dividing. }\end{array}$ \\
$\begin{array}{l}\text { Following the cloning controversy of 2004-2005, in which South Korean } \\
\text { scientists falsely claimed to have used somatic cell nuclear transfer to create } \\
\text { embryonic stem cell lines, the scientific community demanded much stronger } \\
\text { evidence that the procedure had actually been successful. }\end{array}$ \\
\hline Source: Learn Genetics (2017)
\end{tabular}

Today, cloning techniques are more often laboratory confined, with some commercial examples of cloned animals. According to Burgess, (2017) a couple from the UK spent $£ 67,000$ cloning their dead dog. They sent the DNA to a company in South Korea and once cloned the puppies were shipped to the UK. Viagen, A US firm claims to be "America's most trusted animal cloning company". Viagen has claimed to have cloned a range of livestock from cows, pigs, sheep, and goats - including pets. It has also claimed to clone horses, apparently cloning studs to create excellent racing horses, allowing "breeders to better leverage their most exceptional animals". In a conversation with WIRED, the US firm said it had been operating for 15 years in which time it had "cloned thousands of animals" using the SCNT process, and the pets it produces are "normal healthy puppies and kittens". Viagen said "The process of cloning a pet from start to finish can take 8 to 12 months. This is due to the time it takes to create the embryo, the 60-62 days for the dog or cat to experience a normal pregnancy, aftercare of the puppies and kittens before they are given to the pet owner." Another example is Utah State University, who have been cloning cows and the academic institution claims "Cloning is an excellent way to help endangered species, promote disease resistance, or even increase milk production" (Burgess, 2017).

In the journal Nature Communications, authors reported on four of Dolly the sheep 'sister clones'. The study reported that the sister clones seemed to be in relatively good shape and live a healthy life in comparison to Dolly who lived 6.5 years (Sinclair, Corr, Gutierrez, Fisher, Lee, Rathbone, Choi, Campbell \& Gardner, 2016). Explaining the sister clones success Sinclair explains that "They're what we would call genomic copies - they share the same nuclear DNA, they're the same cell line, the same batch of cells in fact that gave rise to Dolly. But of course the eggs in which the nuclei from these cells are injected are from different donors, from different animals, and so they share the same nuclear DNA, but they don't share the same mitochondrial DNA. ... That's why we refer to them as being genomic copies, rather than as purely identical" (Shockman, 2016). According to Sinclair, scientist who have an interest in cloning have changed their focus and methods from the days of Dolly the sheep. More recently, scientist are focusing on IPS cells, also known as induced pluripotent stem cells.

Sinclair stresses that there have been changes for cloning since Dolly, which should bode well for future experiment, noting, "modern protocols now for cloning animals are much more efficient than they were at the time that Dolly was created,"You can now take a differentiated cell and restore it to something like an embryonic cell, capable of dividing into many cell types. "Cloning is still undertaken, particularly in the United States, and the protocols in the news 
today are much more efficient, are much more effective. So we can be hopeful, with the research that's taking place, that in the future we could maybe see more healthy cloned animals like this" in reference to dolly's sister clones (Shockman, 2016). According to Sinclair et al., (2016) future cloning will focus on creating transgenic animals and adding them to the food production chain. "Transgenic animals are those that have had a gene inserted into their genome. This process has the potential to eradicate disease by rewriting genes related to diseases. But this also comes with its own ethical issues and in Europe, for example, there is a ban on introducing cloned animal products to the food chain" (Burgess, 2017). This section has identified that cloning is common practice and the advances in science will further establish human capability in the future.

\section{Future scenarios: Tourism, cloning and animals}

The following section presents three narratives illustrating scenarios in which animals could be cloned in the future for tourism purposes. Karl Schroeder author of the novel, Lockstep, explains the reasoning behind writers exploring the future and the timeframe in which they write, the following comments are Schroeder's reflections regarding fictional future timespan, between 30 - 80 years in the future, to which many authors often seem drawn towards: "In any case it's a focus problem: to look too close to now is to open yourself to irrelevance before you're even published; to focus too far out is to give your readers nothing to care about. There's a sweet spot between thirty and eighty years in the future that a lot of writers gravitate to" Karl Schroeder (in Misra, 2014). The reasoning behind 2070 as the timespan is based on judgments in line with species decline and potential environmental change as identified above in section three. Over the course of the next 45 years, and justified in the discussions above, our planet could witness depleted numbers of species. The potential challenges that face humanity, such as the impact on the natural environment over time. It is thus argued, that there will be failure to support vulnerable ecosystems and climate change will lead to greater areas of land becoming inhabitable for both humans and animals and developments in technology will lead to greater capabilities in animal cloning (explored below). Table 3 presents three short scenarios (narratives) to highlight how tourism and animal cloning could exist in 2070. This is followed by further analysis and discussion, offering critical debates on their future plausibility.

"Human behaviour flows from three main sources: desire, emotion, and knowledge," Plato. Scenario one, desire - "a strong feeling of wanting to have something" (Oxford Dictionary, 2017). In this case the desire is that of the opportunity to pay and eat a cloned animal, one that has long been unavailable to humans. Scenario two, emotion - emotion is any conscious experience characterized by intense mental activity and a high degree of pleasure or displeasure (Cabanac, 2002). Scenario two focuses on a topic that is highly contentions and a subject that has strong levels of emotional attachment for people. Scenario three, knowledge - mankind has shown throughout history to have a thirst for knowledge, understanding, to evolve, and this will continue into the future, and the capability to conserve, learn, and educate through animal cloning and conservation will arguable to exciting to disregard.

Table 3: Animal cloning in 2070: Three future scenarios

\begin{tabular}{|c|l|}
\hline \multicolumn{2}{|c|}{ Scenario One - Food Tourism: Luxury species dining } \\
\hline \multirow{2}{*}{$\begin{array}{l}\text { Habitat change and destruction resulted in specifies extinction } \\
\text { and many others on the brink of extinction. Many of these now } \\
\text { extinct animals were once a long been part of the human food } \\
\text { chain. Japan 2070, offers the ultimate in animal cloning } \\
\text { delicacies. Here tourists have the opportunity to indulge in a } \\
\text { mixture of fine foods, most of which have been extinct in the wild }\end{array}$} \\
\hline
\end{tabular}




\begin{tabular}{|c|c|}
\hline $\begin{array}{l}\text { restaurant } \\
\text { perspective }\end{array}$ & $\begin{array}{l}\text { for decades. Tourists can indulge in a mixture of meats and fish } \\
\text { that have long become inaccessible to the majority of society. } \\
\text { The restaurants offer cloned delicacies for customers; an } \\
\text { experience that is unforgettably tasty. Consumers are required to } \\
\text { pre-order (a few months in advance) rare animals of the past. The } \\
\text { products do not come cheap, especially animals that offer } \\
\text { medicinal benefits, and the restaurants are frequented by the } \\
\text { more affluent clientele. The experience is truly unique to our } \\
\text { times. A service that has boomed as a result in consumer } \\
\text { demand for 'cuisine of the past' and due to the advancements in } \\
\text { cloning technology and the readily available genetic material of } \\
\text { extinct and endangered animals (past and present) that were } \\
\text { stored in what were known as frozen zoos. }\end{array}$ \\
\hline \multicolumn{2}{|c|}{ Scenario Two - Cloning animals for sport hunting } \\
\hline $\begin{array}{l}\text { Sport hunting and } \\
\text { tourism 2070: } \\
\text { Designated } \\
\text { hunting reserves } \\
\text { in South Africa }\end{array}$ & $\begin{array}{l}\text { Over the decades, society got frustrated with the act of sport } \\
\text { hunting as animal population diminished globally. With growing } \\
\text { numbers of animals becoming extinct in the wild, governments } \\
\text { eventually came down hard on poaching and sport hunting. A } \\
\text { global consciousness towards animal welfare ensured the act of } \\
\text { sport hunting continued to be an activity for a small minority. } \\
\text { Nevertheless, sport hunting as a tourism industry continues, } \\
\text { much to its historical roots and the demand. In } 2070 \text {, the sport is } \\
\text { more concealed and removed from the wider public. The } \\
\text { consumers of this sporting activity continue to seek the 'thrill of } \\
\text { the hunt'. Specialist hunters are enthusiastic to test themselves } \\
\text { against predatory animals, similar to societies of the past. } \\
\text { However, with dwindling numbers of wild species it has become } \\
\text { tougher to locate such challenges. However, as time grew, } \\
\text { companies recognised the opportunity of cloning as a means to } \\
\text { satisfy these tourist-hunting desires. Private nature reserves } \\
\text { opened up in various locations around the globe in which cloned } \\
\text { animals are re-introduced into natural habitats and then made } \\
\text { available for hunting - but at a premium price. Wealthy sport } \\
\text { tourism hunters pay big bucks for companies to clone and grow } \\
\text { predatory animals for their hunting desires. And like their } \\
\text { ancestors, they are offered the opportunity of a life time to hunt } \\
\text { animals of a past era. }\end{array}$ \\
\hline \multicolumn{2}{|c|}{$\begin{array}{c}\text { Scenario Three - Cloning animals for education \& } \\
\text { conservation: Future safari zoo }\end{array}$} \\
\hline $\begin{array}{l}\text { Safari-zoo tourism } \\
\text { 2070: Into the } \\
\text { Wild, cloning for } \\
\text { education \& } \\
\text { conservation in } \\
\text { the U.S.A. }\end{array}$ & $\begin{array}{l}\text { With dwindling numbers of wild game in our natural } \\
\text { environments, safari wardens and game parks began to clone } \\
\text { animals as an attempt to save species from going extinct. } \\
\text { Humanity felt responsible for the destruction of animal habitats, } \\
\text { which had huge ramifications for species preservation and } \\
\text { survival as significant global changes occurred in the natural } \\
\text { environment. Consequently, with technological development in } \\
\text { animal cloning, scientists, research centres, universities and } \\
\text { zoological departments along with government funding began to } \\
\text { establish spaces where animal life and species would be able to } \\
\text { flourish. The cloned animals where gradually reintroduced into } \\
\text { the natural habitats and with computer and tracking devices, they }\end{array}$ \\
\hline
\end{tabular}




\begin{tabular}{|l|l|}
\hline & are monitored 24-7. Once previously, extinct species will be \\
viewable to visitors. The fascination of cloned animals adapting \\
and interacting with the natural environment is a popular \\
attraction for tourists. The focus is on conservation and education \\
as tourist are fully informed of the cloning process and the \\
adaption and interaction of animals as they grown up in the \\
natural habitats. The lure for tourists to exhibit 'forgotten species \\
of the past' is seen as a unique selling point for safari-zoo \\
marketers. A once in a lifetime opportunity that is also an \\
expression of humanities capabilities.
\end{tabular}

\section{Animal cloning: The ethical debate}

"Despite all of this scientific research, there has been little public discourse on the many ethical issues raised by animal cloning projects" (Fiester, 2005: 328).

As noted by Fiester (2005), due to the diverse motivations and types of animal cloning that exist, the ethical terrain is complex. The two main areas in which cloning rises moral dilemmas are firstly the negative consequences to animals, human beings, or the environment, this area often referred to as "consequentialist" in nature and focuses on the possible problematic effects that may arise from cloning science (Rollin 1981; Singer 1975). Here, issues raised are the potential pain and suffering caused to animals as a result of the cloning process, the potential of cloning animals leading to human cloning.

Ethical issues relating to animal welfare are defined by the World Organisation for Animal Health as "the state of the animal...how an animal is coping with the conditions in which it lives" (see Ormandy, Dale \& Griffin, 2011). Alternatively, there is the concern that cloned animals could lead to serious environment impacts, either as a result of breeding with nonclones or the potential of an unforeseen expression of a gene, leading to consequences to wider ecosystem. Overtime, arguments are that science will advance and reduce the pain and suffering endured by animals. As for the potential adverse effects to human beings and the environment, a reasonable solution would be to tighten industry regulation. The consequentialist arguments against animal cloning whilst highlighting central concerns, they arguably do not constitute a justification for a blanket rejection of animal cloning.

The other area that often generates significant debate is how animal cloning can violate important moral prohibitions or principles that individuals, groups and societies might embrace. Here, debates fall towards deontological grounds (Regan, 1983), with activist and opposing parties arguing on the ethical grounds and concerns of "playing God," the intrinsic value of the animals, and the objectification and commodification of animals (Fiester, 2005). Advocates of animal cloning argue that we have been modifying organisms throughout human history and the creation of new species through modification is not new (Burkhardt 1998). Furthermore, "if there is a legitimate deontological consideration here, it will need more extensive articulation to persuade proponents of animal cloning that the entire science is morally flawed" (Fiester, 2005: 338). Taking the perspective of an evangelical Protestant Gary Comstock (2001) contends "that God wants human beings to pursue science and endorses scientific endeavors like biotechnology. Cloning isn't playing God-it's doing what God has given human beings the mental gifts to do" (see Fiester, 2005: 338-339).

“...it is not unusual for scientific innovation to proceed ahead of ethical reflection..." (Fiester, 2005: 328-329). 
"We are still in a state of raw lawlessness when it comes to the relationship between generations" (Gaarder, 2016). Our consideration for future generations is short-termism and often self-centred and motivated. "Human nature is characterized by a predominantly horizontal and short-term sense of direction" (Gaarder, 2016). How broad is or ethical horizon? What will the ethical horizon of the future look like? There are questions of identity, culture, societal realities, and ultimately, what is it to be a human being. This paper proposes that, the world in 2070 whilst different to today, will not see any significantly dramatic changes in ethical and moral outlooks, rather, humans will continue to endeavour scientifically, and consequently, animal cloning will remain.

"The balancing of present wants against the future is really the central problem of ethics" Walter Lippmann.

\subsection{Is cloning the solution to save endangered animals}

"Right now, cloning is not a viable conservation strategy. But some researchers remain optimistic that it will help threatened species in the future" (Jabr, 2013).

Researchers often agree that cloning is not a feasible or effective method of conservation as conservationists' stress that cloning does not tackle the reasons as to why many animals become endangered in the first place, such as hunting, habitat destruction and global warming (Jabr, 2013). Holt, Pickard, \& Prather (2004) in a review paper called the prospect of cloning highly endangered species suggested the ideal was "hopelessly optimistic". Further suggesting critics call these efforts stunts, designed to attract attention and potential funding and in so doing reducing the attention that should be given to conserving the habitats species on the brink of extinction (Lee, 2001). According to William Holt "producing the odd animal here and there, which may be sick, didn't seem a very sensible thing to do" (Callaway, 2012). The cloning of animals has stimulated considerable debate globally, with focus on the ethical procedures. There is great need for developmental biologist driving the research to find a balance between their progress, as research should be proactive, encouraged but also cautionary (Holt et al., 2004). Holt et al. (2004: 323) suggest that those who abandon the cautionary considerations "tend to be both highly vociferous and good at capturing media attention". A publicised study to clone a Tasmanian tiger using DNA recovered from a single alcohol-fixed museum specimen generated considerable publicity worldwide, further attracting funding and elevated public expectations of potential success (Anonymous, 2002; Meek, 2002). Holt et al. (2004: 323) recognise that research and stories of such type create an "impression among the conservation community that reproductive and developmental biologists are unthinking zealots who only want to perform the latest hi-tech procedures". Importantly, in a word of rapidly developing cloning technology, developmental biologist should be making strides to "focus on developing realistic strategies for using these methods in wildlife conservation and ensuring that scarce resources are deployed where they will be most effective" (Holt et al., 2004: 323). Other researchers remain unconvinced. Suggesting that "the idea of cloning endangered species trivializes what extinction really is," according to zoologist Robert DeSalle (from the American Museum of Natural History in New York). DeSalle contends that the suggestion is a sign of today's 'Western throwaway society' and that "technology can't solve the problem of large-scale extinction" (Bethge, 2012). The World Wildlife Fund (WWF) is another organisation in opposition to cloning as a quick-fix solution. Once again, highlighting the inability to clone the habitants in which species live. As expert Sybille Klenzendorf from WWF states, "habitats cannot be cloned," and a "species is more than just the sum of its genes. What use is a cloned animal if we have no more space where the species can live? The money would be better invested on direct aid to maintain habitats," (Bethge, 2012). 
Mulligan argued that we have now reached a time in which it is necessary to freeze the cell material of endangered species. With development in technologies humans will have the capability to bring the animals back to life after they have become extinct. "In some cases, it may be cheaper to save some DNA, and let a future, richer and perhaps more enthusiastic generation make its own copy of the species" (Bethge, 2012). According to Martha Gómez (researcher from the Audubon Center for Research of Endangered Species in New Orleans), "technology is a viable way to preserve genetic material for the future." Gomez continues by explaining that embryos cloned today could be stored for decades in liquid nitrogen and reactivated when needed. Casey Mulligan (US economist) wrote, "by bringing cloning into the set of public policy instruments, we can protect more species, reduce economic costs of protection, or both" (Bethge, 2012).

"Cloning is often thought of as unnatural and inhumane, but it was, in fact, the first method of reproduction and is still very common in nature today. Asexual reproduction, the oldest form of cloning, is used by aspens, stick insects and Kentucky Bluegras" (Vannewkirk, 2016).

To date cloning of endangered species has a low success rate and animals that are cloned often have shorter lives and are unable to reproduce. Do to current cloning inefficiencies, environmental leaders are somewhat reluctant to push the matter, as noted by Oliver Ryder (expert at the San Diego Zoo Institute for Conservation Research), suggesting, "the potential of cloning is intriguing, but it's been very little tested in terms of its practical application". Further suggesting that the most successful salvation of species is to preserve them in their natural environment (Vannewkirk, 2016). Current debate would suggest our capabilities are limited in terms of cloning for animal preservation, but what of the future? "Frozen zoos" in San Diego and Brazil hold the genetic material of extinct and endangered animals. The institute's efforts are directed towards eight strategic areas. The first two of which are, "conservation genetics: Sustaining and restoring genetic diversity through bioresource banking and research" and "reproductive Sciences: Applying innovative science and technology to enhance reproduction" (San Diego Zoo Institute for Conservation Research, 2017). With developments in technology (Vannewkirk, 2016) and societal changes, such as peoples attitudes towards cloning, potentially in more desperate times, or in a world where people are more open to the capabilities of explorative science, then cloning animals for either of the above scenarios is not unforeseeable. If researchers manage to dramatically increase the efficiency of cloning wild and endangered animals, it will require the advancement of cloning through nuclear transfer or in vitro fertilization (for more on this see Jabr, 2013), and if achievable, then the DNA they need will be waiting for them at the frozen zoos. Pasqualino Loi of the University of Teramo in Italy was part of a team that successfully cloned endangered mouflon sheep in the early 2000s; Loi suggests that "once cloning of endangered animals is properly established, it will be a very powerful tool," Loi says. "If something can be done, it will be done in 10 years" (Jabr, 2013). Current debates suggest that cloning in its current capacity is limited as a means supporting global food production in the future. However, it does not rule out the possibility of it doing so in 2070, importantly, the scenarios in this research do not point to such drastic necessities of cloning. Instead, the scenarios presented in this paper consider more focused and less expansive acts of cloning.

\subsubsection{Scenario one consideration: Food Tourism: Luxury species dining}

"Just like people have a human right to health care, people have a human right to eat - and we should recognize and honor that act through tangible actions" (Pegoda, 2015).

As noted by Robinson and Getz (2016), food is an attraction in its own right, and in recent years, the sector has matured into a niche tourism market (Kivela \& Crotts, 2005; Okumus, 
Okumus, \& McKercher, 2007). So much so, "destinations are now promoting themselves as centers of food and culture and mobilizing food and beverage products and experiences as attractions" (Robinson and Getz, 2016: 432). And many authors stress that even to date there is limited attention and understanding on the motives of food tourists and the types of experiences, products, attractions they seek (Kivela and Crotts, 2009). This paper, offers an insight into a potential niche market attraction of luxury species dining in the future, and how a destination could distinguish itself by offering tourists an opportunity of a lifetime to pander to their food tourism desires. In this case the tangible action to a right to eat, is through the act of animal cloning.

To clone or not to clone animals for food - that is the question.

The debate on cloning across the globe is vibrant and different regions have taken different attitudes, be it anti cloning, conservative or at the forefront to its progression. In the US, The National Organic Standards Board (NOSB), an expert advisory panel to the USDA's National Organic Program, recently noted "organic agriculture should not allow the use of cloned animals or their offspring in the production of organic food. The NOSB voted at their spring meeting in Washington DC to exclude cloned animals, their offspring, and any food products from cloned animals from the organic sector." Will Fantle of The Cornucopia Institute, a farm policy and organic watchdog group said:

This is a victory for farmers, consumers and retailers who want to protect organic food and agriculture from a highly controversial and experimental technology. This vote seeks to plant a flag squarely in the center of the organic food sector, declaring it off limits to cloning while providing consumers a clear choice in the marketplace (Tourism Futures, 2017).

Whilst eliminating cloned food sources into the organic market is one sector free of twined chickens, what about the rest of the food market? The federal Food and Drug Administration (FDA) has implied that they are ready to support the "commercialization of cloning in livestock agriculture and indicated that they would not seek any identifying labels on cloned meat, dairy and other food products sold in the nation's grocery stores. "More interestingly, are we already eating cloned meat? Despite fierce differences from animal welfare and consumer advocacy groups, environmental organizations, members of Congress, and many consumer, in January 2008, the U.S. FDA permitted the sale of cloned animals and their offspring for food (DeFazio, 2017). "Our evaluation is that the food from cloned animals is as safe as the food we eat every day," said Stephen Sundlof, the FDA's chief of veterinary medicine (DeFazio, 2017).

A study in 2005 by the University of Connecticut concluded that milk and beef from cloned cows did not pose any health or safety threats to consumers. However, critics say that the study was far too limited to yield any meaningful conclusions as the milk and beef were taken from six cloned animals. Furthermore, arguing that the study did not take into account whether clones were more susceptible to infection or other microbial problems, as many scientists suspect (DeFazio, 2017). The Washington, DC-based Center for Food Safety, in a petition filed in 2006, declared: "The available science shows that cloning presents serious food safety risks, animal welfare concerns and unresolved ethical issues that require strict oversight." The group announced on September 2, 2008 that 20 leading U.S. food producers - including Kraft Foods, General Mills, Gerber / Nestle, Campbell's Soup and Ben and Jerry's, will not use cloned animals in their products. "The move by these companies represents a growing industry trend of responding to consumer demand for better food safety, environmental and animal welfare standards," the group said in making the announcement (DeFazio, 2017). The European attitude is forced by a strong public opinion against cloning of any kind, thus, the European Union does not allow the practice in animal husbandry. However, even European markets are not clean of cloned consumptive products. Officials accept that milk or meat derived from cows with a cloned ancestor may have directly or indirectly got into the market, either attained from a live imported animal, or possibly from an animal bred domestically from 
genetic material brought into the EU. "Without knowing it, Europeans are probably eating meat from the descendants of clones that cannot be traced," said Pauline Constant, spokeswoman for the European Office of Consumer Associations, based in Brussels (AFP, 2016). Clearly, the debate and attitudes vary, and at present there are tentative attitudes and remarks and observations from the associated industries and sectors towards animal cloning as a source for food.

Endangered animals are still on the menu!!! Even in a world where animals are endangered and risk extinction, human desire to consume endures. Species around our globe are threatened and risk extinction as a result of many factors from habitat loss, pollution, climate change, competition from invasive species and overhunting. Additionally, a number of animals on the verge of extinction continue to be hunted for their meat. In some circumstances people are impoverished and have limited sources of food, however, in some case species are poached to satisfy a culture's appetite for exotic delicacies (Nelson, 2010). According to a report by Ripple, et al. (2016) the drivers for mammal hunting and the primary motives for hunting and trapping threatened species is to acquire meat for human consumption and is associated with developing countries in continents such as Africa, South America and South East Asia. Other main motives for hunting include consumption for body parts as traditional medicine, capture of live animals for pet trade, and ornamental use of body parts. It is well documented that unsustainable hunting for consumption and trade of wild meat (also known as bushmeat) by people represents a substantial extinction threat to wild terrestrial mammal populations. Again, continents that are often identified are parts of Asia, Africa and South America (Fa, Peres, Meeuwig, 2002; Milner-Gulland, \& Bennett, 2003; Darimont, Fox, Bryan \& Reimchen, 2015). Table 4 presents a list of endangered species that continue to be hunted for their meat for human consumption.

Table 4: Endangered species still on the menu

\begin{tabular}{|l|l|}
\hline Animal & On the table \\
\hline $\begin{array}{l}\text { Chinese Giant } \\
\text { Salamander }\end{array}$ & $\begin{array}{l}\text { The Chinese Giant Salamander the largest amphibian in the world is a delicacy } \\
\text { in China and the target of illegal hunting. }\end{array}$ \\
\hline $\begin{array}{l}\text { Chimpanzees \& } \\
\text { Gorillas }\end{array}$ & $\begin{array}{l}\text { The consumption of bushmeat, often originating from great apes like } \\
\text { chimpanzees and mountain gorillas, is a cultural tradition in parts of Africa and } \\
\text { it is not viewed as a problem. The species are also suffering a population } \\
\text { decline due to deforestation and habitat loss. }\end{array}$ \\
\hline Chinook Salmon & $\begin{array}{l}\text { Chinook salmon, found exclusively in the Pacific Northwest, have been on the } \\
\text { steady decline for years due to damming of rivers, pollution and over-fishing. } \\
\text { While commercial fishing in some areas is subject to annual approval, officials } \\
\text { kill sea lions - natural predators of salmon - in order to allow more salmon } \\
\text { stocks for fishing in the Columbia River. }\end{array}$ \\
\hline Big cats & $\begin{array}{l}\text { Believe it or note, lion meat burgers were prepared by an Arizona restaurant in } \\
\text { celebration of the World Cup soccer tournament in South Africa. The story } \\
\text { behind how a restaurant in Arizona got its hands on lion meat is a prime } \\
\text { example of how trade in exotic, endangered animals is an international racket. } \\
\text { All of the world's big cats, though especially lions and tigers, are occasionally } \\
\text { poached for meat and questionable medicinal purposes. }\end{array}$ \\
\hline Bluefin Tuna & $\begin{array}{l}\text { When an endangered species swims under the sea, people tend not to give as } \\
\text { much pause before taking a bite. Bluefin tuna is a favorite for sushi in Japan, } \\
\text { and despite its incredibly endangered status, is still commercially harvested and } \\
\text { sold. }\end{array}$ \\
\hline Chinook salmon \\
$\begin{array}{l}\text { Chinook salmon, the largest of the salmon family, are native to the Pacific Coast } \\
\text { and are highly prized among the species because of their size. As many as nine } \\
\text { subspecies of these fish are protected under the U.S. Endangered Species Act. } \\
\text { Fisheries are regularly closed in California and Oregon due to low numbers of } \\
\text { the fish. }\end{array}$ \\
\hline
\end{tabular}




\begin{tabular}{|c|c|}
\hline Caribou & $\begin{array}{l}\text { Caribou populations across North America vary from burgeoning to sparse, but } \\
\text { despite protection, the rare populations are still hunted. For instance, the Innu } \\
\text { in Quebec hunt the animals from snowmobiles and will slaughter entire herds. }\end{array}$ \\
\hline Pangolin & $\begin{array}{l}\text { Found in tropical regions of Africa and Asia, these cute but scaly creatures are } \\
\text { most threatened in China, where they are considered a delicacy and are } \\
\text { occasionally consumed for unfounded medicinal reasons. There's even a dish } \\
\text { in Indonesia called "pangolin fetus soup," which locals believe can increase a } \\
\text { man's virility. Pangolins are also under threat of extreme habitat loss, as forests } \\
\text { are rapidly cleared to make room for agriculture and development. }\end{array}$ \\
\hline Fin Whales & $\begin{array}{l}\text { The Japanese whaling fleet claims to kill whales for research, yet not a single } \\
\text { study has been published based on their annual hunt. In addition to hundreds } \\
\text { of Minke whales, the ships slaughter a few dozen endangered Fin whales every } \\
\text { year, which inevitably end up in cans on store shelves. }\end{array}$ \\
\hline Giant ditch frogs & $\begin{array}{l}\text { The endangerment of the giant ditch frog due to demand for frog legs is a good } \\
\text { example of what is happening to many of the world's endangered frog species. } \\
\text { In the last } 10 \text { years, the giant ditch frog population has plummeted by } 80 \\
\text { percent, primarily through consumption. Aside from overhunting, frogs } \\
\text { worldwide also must contend with habitat loss, pollution and the fungal disease } \\
\text { chytridiomycosis, which now threatens almost all frog populations. }\end{array}$ \\
\hline Green sea turtles & $\begin{array}{l}\text { Although they are greenish in color, these sea turtles get their common name } \\
\text { from the green fat found beneath their carapace. Now protected from } \\
\text { overexploitation by the IUCN and under CITES, green sea turtles are } \\
\text { nevertheless still under threat because they are illegally harvested for food } \\
\text { throughout their life cycle. Because they migrate such far distances, their } \\
\text { survival truly requires international awareness. }\end{array}$ \\
\hline $\begin{array}{l}\text { African Forest } \\
\text { Elephants }\end{array}$ & $\begin{array}{l}\text { Elephants are famously poached for their ivory, but forest elephants - the most } \\
\text { at-risk elephant species in the world - are also hunted for their flesh. The } \\
\text { animals weigh over 5,000 pounds but only yield 1,000 pounds of meat. } \\
\text { Combined with the ivory, one elephant kill can land a poacher thousands of } \\
\text { dollars. }\end{array}$ \\
\hline Manatees & $\begin{array}{l}\text { Manatees have long been targeted by hunters because of their plump shape } \\
\text { and sedentary lifestyle. Shortly after the arrival of Christopher Columbus, the } \\
\text { hunting of manatees became widespread in the Americas. Although they are } \\
\text { protected by federal law in U.S. waters, the animals are not so lucky elsewhere, } \\
\text { where they can still be targeted for their meat. }\end{array}$ \\
\hline Green Sea Turtles & $\begin{array}{l}\text { Green sea turtles are hunted for their shells, leather, flesh and fat. Their eggs } \\
\text { and meat used to be a delicacy in Hawaii before the Endangered Species Act } \\
\text { granted them protection in } 1977 \text {. However, the turtles are still hunted in } \\
\text { Indonesia and other countries in South Asia. }\end{array}$ \\
\hline River Dolphins & $\begin{array}{l}\text { Freshwater dolphins - found in the Ganges, Indus and Amazon rivers - suffer } \\
\text { from naturally low populations, so the impact of pollution and hunting has been } \\
\text { drastic. A species in the Yangtze river was driven to extinction in 2006, the first } \\
\text { mammal to go extinct in } 50 \text { years. }\end{array}$ \\
\hline Gaurs/Seladangs & $\begin{array}{l}\text { The gaur, a wild relative to the cow, is a threatened species found in South Asia. } \\
\text { While domesticated gaurs called gayals are common, the wild herds are still } \\
\text { hunted for their meat. The animals have few predators other than tigers, which } \\
\text { they've been known to fight off and kill. }\end{array}$ \\
\hline Sharks & $\begin{array}{l}\text { The Ganges Shark is hunted from the river's muddy waters for its nutrient-rich } \\
\text { oil. Dozens of other species across the world are becoming endangered from } \\
\text { the practice of shark finning, where fisherman slice off the fins of live sharks } \\
\text { before tossing the animals back into the water to drown. The fins are dried and } \\
\text { used to make soup in Asian restaurants. }\end{array}$ \\
\hline Markhor & $\begin{array}{l}\text { A large, mystical-looking species of wild goat native to Afghanistan and } \\
\text { Pakistan, fewer than } 2,500 \text { mature markhors remain, with a } 20 \text { percent decline } \\
\text { in the population as a whole over the last two decades. And yet, the animal } \\
\text { continues to be hunted for its meat. It's likely that the war in Afghanistan may } \\
\text { be intensifying the hunt, as fighters take refuge in the mountains where } \\
\text { markhors live. }\end{array}$ \\
\hline
\end{tabular}


Whilst it is suggested that in the US companies typically produce hundreds or a few thousand clones per year, and in Europe, there is the potential for people to be consuming food without knowing what they are actually eating - recall $100 \%$ horse meet lasagne and not beef scandal (BBC, 2013). In contrast, the Boyalife Group's cloning new factory near the northern coastal city of Tianjin in China is said to be aiming for an annual output of 100,000 cows in 2016 with a projected increase of one million by 2020 . The future will also see cloning of thoroughbred racehorses, pets and police dogs specialised in searching and sniffing (AFP, 2016; Lepore, 2015). Clearly, the market exists, and in some regions of the world, there is much movement towards cloned animals. Will larger numbers of human population globally further drive the demand for meat consumptions, in a world where food supplies could become scarce?

"Every year, on the first Saturday in January, Japan makes a grand statement to the global fishing community by putting an exorbitant price on the head of a single bluefin tuna. At the famous Tsukiji fish market in Tokyo, the first bluefin auction of the year represents many things: growing consumer demand for bluefin sashimi, the exploitation of natural resources, the collapse of a species, shortsightedness in the face of impending doom to the entire ocean, a depraved publicity stunt" (Narula, 2014)

Kiyoshi Kimura the owner of a Japanese sushi restaurant chain in 2013 paid $\$ 1.76$ million for the first bluefin at Tsukiji, which weighed 489 pounds. In scenario one, the author suggests that in the future, 2070, there is the potential that restaurants in Japan will offer consumers the opportunity to pre-order cloned meat to satisfy their gastro-desires, of course, the experience will come at a price relative to the times. If consumers in today's market are willing to eat animals on the brink of extinction for top dollar, what will the price be for cloned delicacies, especially if sold with medicinal benefits? Whilst, at present the ethical debates continue, there is a potential that somewhere in the world (Japan offered as the case in this instance), that people will be allowed to pay for cloned meat. The future will likely see contrasting views of cloning animals for consumption, but it should not be discounted as a possibility, especially if the price is right.

\subsubsection{Scenario two consideration: Cloning animals for sport hunting}

The importance of geographical segmentation of active sport tourism markets have been explored in current literature (Hinch \& Highman, 2011) and considered in the scenario above. Geographical segmentation focuses on both the origins of the visitor (the sport hunter and generating regions) and the market location, where the activity takes place. Consideration of this is highly significant, as geographical locations allow for varying forms of sporting behaviour and activities to play out. This can be a result of terrain, weather conditions, and the natural and man-built environments that exists, providing enhanced conditions (Bale, 1989; Rooney \& Pillsbury, 1992). Additionally, attitudes, standards, ethical and social behaviours change over geographical locations, and thus, allow for different activates to exist. In the current scenario, South Africa is selected as the geographical location, much to its current engagement with sport hunting and tourism.

Hunting is a practice whose roots can be located back to pre Homo sapiens (Gaudzinski, 2004; Rabinovich, Gaudzinski-Windheuser, \& Goren-Inbar, 2008), and evidence from research conducted by Wong (2014) in a paper entitled, "how hunting made us human", suggests that hunting has taken place for more than 2 million years. As evidenced in this research, hunting is common in today's society and the likelihood is the practice will continue in the future. It is not necessary to identify a specific geographical segmentation in reference to generating regions of tourists, but what is important to recognise is the importance of identity in active sport hunting participation. Yinger (1960) refers to the term, 'unique ethos', which is the "conceptualization of a subculture as a normative system used to set a group apart from a larger whole" (in Jones \& Green, 2006: 40). Activities such as sport hunting exist in their own 
independent social worlds, and the participants of the different (sport and leisure) activities represent a distinct segment within those social worlds. These groups of individuals adhere to a set of norms, values and behaviours that differentiate them to the wider social environment. Even within these participatory social worlds exist different forms and levels of involvement (Jones \& Green, 2006). In line with sport hunting, there exists a social world that conflicts with other members of the wider global community. Nonetheless, sport hunting is a subcultural world that exists, an identity and a sport that individuals (participants) align themselves to, taking on shared symbols, ideologies, values and behaviours. Thus, scenario two offers a future subculture in which sport tourists are willing to pay for the opportunity to hunting cloned animals, in a geographical location, which offers different social and cultural attitudes from other global communities.

Hunting can be associated an activity for the acquisition of bushmeat / food, in reference to scenario one. The impacts of mammal hunting on endangered species varies across continents and is said to not reflect patterns of global mammal distribution and richness (Jenkins, Pimm \& Joppa, 2013). According to their report, there are 301 mammals that are threatened by human hunting and the majority of these are located in developing countries, whilst only eight of these species are also found in developed countries. The authors suggest that a huge contrast in dietary patterns, wildlife management and conservation efforts between the developing and developed world could be a reason for this. It is recognised that there are 113 species threatened by hunting in Southeast Asia (13\% of all threatened mammals are east of India and south of China), 91 in Africa (8\%), 61 in the rest of Asia (7\%), 38 in Latin America (3\%) and 32 in Oceania (7\%) (Jenkins, Pimm \& Joppa, 2013). Interestingly for scenario two is the shift of hunting as a subsistence activity to a more social and leisurely one. There is extensive evidence and material written to advocate the massive slaughter of animals for entertainment and the enjoyment of spectators. Hankcock (2001) devotes a whole chapter to this, providing examples such as "the slaughter of lions and leopards in a simulated hunt" in 186 B.C. in Rome, and in 80 B.C. the killing of nine thousand wild animals (including lions, leopards, elephants, rhinoceros and monkeys) at one event - deemed normal to the times.

Manning (1993) identifies how poaching, or unlawful hunting, was a phenomenon dating back to the Anglo-Norman age. During these times feudal monarchs attempted to declare exclusive hunting rights over vast game reserves designated as royal forests and chases. Two significant trends gradually emerged which allowed the hunting for leisure proposes to evolve. One was the advancement of the specialist hunter, alongside the expansion of training and equipment, and the second, was the importance of co-operation in hunting as a "sport" (Machiavelli, 1531: 519). Manning (1993) notes that poaching, or unlawful hunting, was a persistent phenomenon and dates back to the Anglo-Norman age when feudal monarchs endeavoured to proclaim exclusive hunting rights over vast game reserves designated as royal forests and chases. Sport hunting has often been associated with the upper class and aristocrats of society (Machiavelli, 1531: 519). According to Moryson (1617), in reference to hunting, "no nation so frequently useth these sports as the English". According to Manning (1993), hunting was an integral component of aristocratic culture; a well-regarded and timeconsuming activity. With hunting, (lawfully and unlawfully) came a sense of aura, danger and adventure. The younger gentleman (of upper class society) saw hunting as an opportunity to establish a worthy self-image, by displaying and overcoming difficult feats, with acts of courage on display.

Burton (1621) pronounced hunting as "the sole almost and ordinary sport of all our noblemen,... tis all their study, their existence, ordinary business, all their talk, and indeed some dote too much on it; they can do nothing else, discourse of nought else" (Henricks, 1991: 118). Petit-Dutaillis (1914: 211) delivered the following, "We need only recall how great a part was played by the chase in the life of a medieval man. It was the favourite sport of the nobles; in time of peace it offered a substitute for war..." A common subject for writers in the Renaissance period was the notion that hunting was used as rehearsal for war, because the 
'ancient' societies, specifically kings and warriors, often commended and pursued hunting as a pastime. Thus, hunting was an opportunity to prepare for war, and was seen as a symbolic substitute for war in England during periods when full-scale combat was limited (Manning, 1993). Hunting is not new and sport hunting is not a novel activity. Over time and space, the pursuit has developed, evolved and impacted wider territories, and continues to have its primary motivation as a practice of attaining food and as a sporting leisure activity.

Sport hunting has long been part of the tourism industry and the categories of consumption can be located within many tourism concepts, such as cultural, ecological, nature, hunting, recreational, sports, and trophy hunting (Petroman et al., 2015). Sport hunting can exist on different levels of specialism. Whilst less specialist trophy hunting activities exist globally, with tourists blowing up cows with rocket launchers in Phnom Penh, Cambodia (Baulch, 2013). There is the often disputed fox hunting in the United Kingdom and Ireland.

"What can be better than a day's fox hunting in Ireland? The cry of the hounds, the sound of the hunting horn, the thrill of jumping over natural fences, and the sheer style of this equestrian sport is available to everyone at Flowerhill. Why not join us for the fox hunting holiday of a lifetime?" (Flowerhill, 2017)

London Prime Minister (at the time of writing) Theresa May defended her support for fox hunting, saying that other methods of controlling fox numbers can be "cruel" (Bienkov, 2017), a very much contested debate of our times. With different hutting societies globally, an example is Safari Club International (SCI), who recognise themselves as: The Ultimate Sportsman's Market, boast a club membership of 55,000, and as they state:

"Safari Club International is the leading voice in the fight to protect our freedom to hunt, both in the United States and internationally. The SCI Hunter Advocacy department is headquartered in Washington, DC, advocating on behalf of SCI members and non-members alike. From staff dedicated to legislation and policy to a team of litigators, SCl Hunter Advocacy is at the forefront of protecting our hunting heritage" (SCI, 2016).

SCl keeps a comprehensive record of its 55,000 members', which include photos and information on the animals they have killed. The SCl offer awards and certificates for their members and there are a mixture of hunting big game categories. "Annually, the SCI Record Book recognizes all hunters who have achieved exceptional levels of big game hunting over the past year in a special awards issue of SAFARI Magazine" (SCI, 2017). Their awards to members include the following: 'The Africa Big Five', which requires a hunter to kill an African lion, an African elephant, an African leopard, an African rhino and an African buffalo; 'Bears of the World', hunters must kill four of eleven types of bears; 'Cats of the World', hunters must kill four of seven types of cats; 'Spiral-horned Animals of Africa', here a hunter needs to kill 17 different types of animals; 'Inner Circle', Awards recognize various hunting achievements, such as killing animals with a handgun; and to win the highest SCI award, known as 'World Hunter of the Year', a hunter must kill more than 300 animals across the globe (Humane Society, 2016). In a recent article by Argus (2017) headlines with, "when game parks become killing fields: many of the animals tourists come to see are later hunted". The article discuss how private game reserves with open fences to Kruger Park have applied for approval to shoot to kill 34 elephants, including a trophy bull, and 5,444 other animals such as rhinos, lions, leopards and buffaloes. The reserves in discussion are Associated Private Nature Reserves (APNR), consisting of Timbavati, Klaserie, Balule and Umbabat, reserves that contain luxury lodges catering for tourists who pay high rates to experience exciting wild animal sightings. Hunting is perfectly legal in a reserve like Timbavatim, and primary hunting accounts for $61 \%$ of the reserves income again 17\% provided from tourism (Argus, 2017).

The past and present are filled with different levels of human engagement with hunting animals. The possibility of future tourism hunting could be displayed in different forms. 
Scenario two explores a future where tourists will have the opportunity to have animals cloned in order to satisfy their desires for hunting. With a big game and large numbers of species potentially being extinct, what price will wealthy sports hunters be willing to part with for a once in a lifetime opportunity to hunt a formerly extinct animal in a South African private game reserve? Here the potential for ethical debate regarding animal welfare is much more controversial, and the idea of purposefully cloning an animal for hunting cravings is clearing going to provoke an emotion debate let along ethical one. However, hunting is a practice that humans have long been partaking in and at present the ethical debates have not stopped the practice from evolving over time and place. At first, the practice might be somewhat underground, out of public scrutiny, a taboo of the future, but eventually, it could become a more common and recognisable tourism activity.

\subsubsection{Scenario three consideration: Cloning animals for education and conservation: Future safari zoo}

"Just as the struggle for human rights never ends, the struggle to preserve the ecosystems and the biological diversity of this planet will never end" (Gaarder, 2016).

There is common debate between the conservation of habitats and that of species, in reference to which is more likely to allow species to flourish in the future. Many argue it is the former, habitat conservation that will best support species preservation. However, with growing numbers of humans, the fight for land will continue, and humans are likely to push animal species out of their natural environments, limiting their ability to survive. Thus, leading to Daniel Ashe (director of the Fish and Wildlife Service) to pose the following question "we have to prepare ourselves to make better choices about what is going to come along for the ride with us and where and in what numbers" (see Goode, 2015). There is a difficult debate surrounding the conservation, support and funding of individual species in danger of habitat destruction and potential extinction. In an article by Goode (2015) My Ashe said there is no biological or ethical framework for making such decisions, suggesting, it is a topic that few environmentalists want to discuss. "They either close their ears or they criticize you," Mr Ashe said. Mr Ashe noted that one environmental advocate called even the idea of making choices among species "the height of biological arrogance." Another said that to do so was immoral.

"The onus is on zoos to show an educational mission, to have a potential to do more than entertainment" Daniel Blumstein, chairman of UCLA's department of ecology and evolutionary biology (Milman, 2016).

"If you wanted to design a zoo for conservation, that would be very different from an entertainment zoo," said Ben Minteer, an ethicist at Arizona State University (Milman, 2016).

The origins are with the elite, where the powerful and the wealthy kept exotic animals as pets or as entertainment objects, and todays zoo's can be traced back to the elitist desire to obtain glamorous animals (European Tourism Futures Institute, 2012). The argument for the future here, is whether the tourist experience will be seen as more important or the welfare of the animals. "Zoos have tried to change their mission and some have done that better than others," said Daniel Blumstein, chairman of UCLA's department of ecology and evolutionary biology. "The onus is on zoos to show an educational mission, to have a potential to do more than entertainment" (Milman, 2016). According to Ron Kagan (long-time executive director and chief executive officer of the Detroit Zoo) "The rapidity at which society, at least in the U.S., is changing its views on the ethics of exotic animals in captivity may be outpacing the slower evolution of the zoological profession's moral compass. Kagan suggests that in the future "zoos will surely look and act radically different in 20 years, never mind 50. "Immersion" exhibits will legitimately become natural spaces that are enormously larger and more complex 
than they are today." The zoos of the future will be located in climatic regions that are more suitable to the species, offering more natural and socially friendly environments and activities to take place for the animals, with a focus on the animal's needs and desires rather than the tourist - more in line with a wild habitat and that which is experienced in safari tourism. Kagan suggests, "the animals, both individuals and species, that live in future zoos will only be ones that truly thrive and / or that are "rescued" from a worse fate. Our amusement and selfish, albeit often well-meaning, desire to be close to other species isn't enough to justify their lifelong frustration. Of course that's also true today" (see Brulliard, 2016). According to Rob Vernon (spokesman for Association of Zoos and Aquariums, AZA) "We are seeing an evolution of people's thinking of what a modern zoological institution should be. In the past 10 to 15 years we've seen a dramatic shift in how AZA members approach the public display of animals. We see much larger, more open exhibits based upon modern science" (Milman, 2016). Therefore, the likelihood is that over time zoos will evolve and grow to meet the demands of public opinion and the welfare of the animals. An example or possible model for a zoo that offers a more park / safari-like environment is Denmark's "Zootopia" - a venue where animals roam free, liberated from cages and tanks, while visitors spy upon them from unobtrusive pods buried underground. "This is a future of a zoo as an immersive experience," said Ben Minteer, going on to say that "Zoos have gone through a series of revolutions to get away from artificial environments and the Zootopia idea is the latest step forward with that" (Milman, 2016).

"We can see change in zoos over the next 20 years but I really hope there's something left of the wild in 20 years too. I hope the last elephant, or the last giraffe, isn't the resident of a zoo. If you respect animals and nature, you have to secure their habitat" as highlighted by

Priscilla Feral president of Friends of Animals (Milman, 2016).

David Hancocks suggests the following about zoos and their designers, "these people aren't designing for the animals, they create exhibits in which they can put animals on show" (Worland, 2017: 57)... Zoos are more interested in the illusion of making visitors think animals are well cared for than in actually helping them" (Worland, 2017: 59). Future zoos will look different to the parks that we engage with today. Jon Coe (a visionary architect landscaper) envisioned three types of zoo sizes for the future, as presented in table 5 . The elite mega zoo offers a similar consideration taken by scenario three in this research, a space offering animals an environment to roam, generously open habitats whilst also offering tourists the opportunity to view the animals in a "safari-like setting".

Table 5: Jon Coe's future zoos

\begin{tabular}{|l|l|l|l|}
\hline \multicolumn{1}{|c|}{$\begin{array}{c}\text { Zoo } \\
\text { Name }\end{array}$} & \multicolumn{1}{|c|}{ Description } & \multicolumn{1}{c|}{ Animal benefits } & \multicolumn{1}{c|}{ Tourist benefits } \\
\hline $\begin{array}{l}\text { Elite } \\
\text { sedia- }\end{array}$ & $\begin{array}{l}\text { Suitable for smaller } \\
\text { mammals or limited } \\
\text { numbers of larger } \\
\text { animals. These zoos } \\
\text { might focus on a single } \\
\text { category, like big cats. }\end{array}$ & $\begin{array}{l}\text { These zoos could } \\
\text { focus on just a few } \\
\text { large animals but } \\
\text { provide them with } \\
\text { ample space to } \\
\text { roam. Animals could } \\
\text { explore via } \\
\text { pathways in the air } \\
\text { and on the ground } \\
\text { that link habitat } \\
\text { areas }\end{array}$ & $\begin{array}{l}\text { Interactive exhibits could } \\
\text { highlight conservation and } \\
\text { offer visitors experiences } \\
\text { beyond seeing real-life } \\
\text { animals }\end{array}$ \\
\hline $\begin{array}{l}\text { Elite mega } \\
\text { zoo }\end{array}$ & $\begin{array}{l}\text { Any species, thanks to hundreds of } \\
\text { large roaming areas. } \\
\text { Zoos like this may also }\end{array}$ & $\begin{array}{l}\text { acres, there would } \\
\text { be a large space for }\end{array}$ & $\begin{array}{l}\text { Visitors could view the } \\
\text { animals in safari-like } \\
\text { settings. Commercial }\end{array}$ \\
\hline
\end{tabular}




\begin{tabular}{|l|l|l|l|}
\hline & $\begin{array}{l}\text { become the home of } \\
\text { large animals like } \\
\text { elephants. }\end{array}$ & $\begin{array}{l}\text { animals to roam. } \\
\text { Some exhibits would } \\
\text { combine species to } \\
\text { simulate wild } \\
\text { ecosystems }\end{array}$ & $\begin{array}{l}\text { elements like restaurants } \\
\text { and hotel space could turn } \\
\text { zoos into luxury vacation } \\
\text { destinations }\end{array}$ \\
\hline $\begin{array}{l}\text { The high- } \\
\text { rise zoo }\end{array}$ & $\begin{array}{l}\text { Groups of animals that } \\
\text { can be confined to a } \\
\text { narrow space. These } \\
\text { could include aquatic } \\
\text { species along with a } \\
\text { slice of the rain forest. } \\
\text { Birds could use the } \\
\text { space as a habitat } \\
\text { while also spreading } \\
\text { their wings in the open } \\
\text { air. }\end{array}$ & $\begin{array}{l}\text { Nocturnal species } \\
\text { could rotate with } \\
\text { diurnal ones, } \\
\text { keeping the zoo } \\
\text { open 18 hours a } \\
\text { day. These zoos } \\
\text { could include small } \\
\text { and vertically } \\
\text { oriented animal } \\
\text { communities, such } \\
\text { as in a rain forest }\end{array}$ & $\begin{array}{l}\text { Sea, cliff and forest } \\
\text { attractions could be linked } \\
\text { by special tubes to give } \\
\text { visitors an underwater } \\
\text { view of an ecosystem. } \\
\text { Canopy walkways and } \\
\text { tree houses could also be } \\
\text { integrated. These zoos } \\
\text { could be built into existing } \\
\text { high-rise commercial } \\
\text { buildings with residential } \\
\text { communities. They could } \\
\text { include several } \\
\text { interconnected towers with } \\
\text { themed restaurants, } \\
\text { shopping and hotels in } \\
\text { addition to the animals }\end{array}$ \\
& \multicolumn{2}{|l}{} \\
& \multicolumn{2}{|l}{}
\end{tabular}

The European Tourism Futures Institute also provide a report documenting four potential scenarios for the future of zoos. The data was gathered by an extensive review of literature and a purposeful sampling group of eight experts and well-known figures in the world of zoos. In their scenarios, there is a focus on three main pillars, conservation, education and entertainment. The four scenarios are:

1. The $5^{\text {th }}$ Generation Zoo: a combination between the experience economy and nature immersion plus a focus on the world and advocating on behalf of the importance of nature and its diversity; an ambassador with sustainable solutions.

2. The Commercial Zoo: a nature-like park with a commercial edge where sponsors and commercial venues are present. A media presence is also visible and sustainability is part of the concept.

3. The Modern Zoo: more modern functionalism than the importance than nature. Also a focus on the commercialisation is present within this scenario, but the designers keep in mind the importance of enrichment and such criteria, because they have a function within zoos.

4. The Design Zoo: next to areas of nature in the enclosures, there are cartoonish paintings, giving it a colourful, warm and in-depth feeling. The advocate role is also important within this scenario, as is educating the zoo's visitors about the possibilities within sustainability (European Tourism Futures Institute, 2012).

The position taken in scenario three in this research is that over time there will be a greater focus on educational and conservational approaches, taking the animal welfare as priority. Scenario three suggests that in the future humans will clone endangered species and or extinct animals for the purposes of education and conservation. However, it is suggested that over the course of the coming decades, the zoo as we know it today will change. In time, there will be a focus on creating and establishing large habitats for animals to enjoy, more like a safari, but still aiming to maintain a level of control and management which is more suited to a zoo. This paper is contemplating a space where society can continue to express human development in line with progressions in cloning. If cloning has a place in the future, then a 
safari-zoo attraction to display human accomplishments and advancements and the latest cloned animals (potentially animals that were once extinct) will arguably have a highly desirable pull from a tourism perspective. An idea supported by Ingham (2015) who notes:

"Even for animals that have already gone extinct, all is not lost. However bizarre it may seem, some animals could be brought back to life. There are a variety of ways this process known as de-extinction - could work, the most popular of which is cloning. We could even see the growth of Jurassic Park-like safaris, where visitors can see animals in the flesh that

had previously been long-extinct, bringing a whole new meaning to extinction tourism."

\section{Demand and supply: The future tourist consumer and the marketplace}

"Through tourism the world has developed a platform for people of exceptionally different locations and viewpoints to come together" (Mendiratta, 2011: 24).

As noted by Leigh (2013: 16) tourism is and will likely continue to be a human activity and is "subject to the general circumstances extant at any particular time." In the future tourism will be modified, and or transformed and will fit within the looming society's new context and therefore the lifestyle and limits of such a future society (Leigh, 2013). Any future in which humans persevere or flourish needs to be accompanied by a constant need to examine what it will be like to be human in that future. Thus, one must separate their own believes, morals, and attitudes and contemplate how a human society might act and behave, in a time that is potentially considerably different to present day (and all the events and changes that have led to that future). Then in this context, one can make room for contemplating how tourism and tourists might act out their leisurely activities. The scenarios above will be driven by consumer demand and fuelled market opportunities in a world that has moved on and developed from today's society.

As Yeoman (2008) notes, "Tourists cannot be labelled accordingly to their attitudes and beliefs - what they say and what they do, are two totally different things. They constantly evolve and seek something new..." (in Yeoman, 2012: 52). Yeoman (2012) offers his insight into the future tourist. Suggesting that in the future (2050) there will be rising incomes and wealth accumulation distributed in different ways, which will in time shift the balance of power in tourism. The power balance will have shifted from the travel agent to the individual. An individual that will be able to travel anywhere in the world due to an ever growing interconnectedness of networks, communication and variety in the future market place; less restricted by background and geography. One can at present only stipulate towards future tourist behaviours, trends and travel patterns, and according to Becken (2013) in the future consumers will be more demanding in their travel experiences, more activity based than placebased. Consequently, it is suggested that the future will see more specialized products that serve niche markets, greater demand for luxury products, and educational experiences and a demand for authentic experiences (Becken, 2013).

As discussed by Lemelin et al, (2011) in the past and even today tourist motivation was driven by the need to 'be the first' which facilitated a rush to exotic destinations. In contrast, more common today and in the near future due to our rapidly changing world, the rush, the motivation, the travel phenomena, will be driven by being 'one of the last'. Tourists will be driven by the need and desire of the last chance to consume, collect, or photograph rare or exotic species (Lemelin et al., 2011). The three scenarios presented above are suggested to be tourism experiences potentially reflecting society in 2070 . A world removed from present day, a society that has advanced and experienced changes in social, technological and political environments. Importantly, potentially a society that was not offered the chance to witness and engage with some of the beautiful natural environment that we are fortunate to be living and present with - not fortunate to experience 'the last' exotic animals, to enjoy the 
taste of a rare fish, or the opportunity to hunt a wild cat in its natural habitant or to see an elephant mother give birth - because today's society will have consumed species in many ways to the brink and for some, complete extinction. If consumers are presented with an opportunity to once again 'be the first' to gain a new experience and can pay for such experiences, then the above scenarios have every potential of becoming real.

\section{Conclusion}

The purpose of this research was to offer original insights into the future of tourism. The focus in this research was to consider the current depletion in animal species and how cloning in the future could have a role in supporting tourism consumer experiences. It is suggested, if society continues to destroy the natural habitats of species, large scale species extinction could surface, a point in case that has been explored and supported through extensive reports and evidence highlighting the potential consequences humanity could soon encounter. In the following decades, technological development will see advancements in animal cloning. Conservationists and zoological departments are already storing genetic material of endangered species, with future generations and opportunities in mind. This research has thus offered three scenarios in which the future tourism industry might take advantage of such future thinking. The paper offers three future scenarios in which cloning and tourism could be partnered to meet the demand and leisure and travel pursuits of future tourists.

Based on past and current knowledge and potential future developments, this paper presents three future scenarios. Scenario one explores the potential opportunity for tourists to pre-book / order cloned animals to be eaten in luxury restaurants, after all, humans like to eat, and in this paper, in the future food will continue to be a priority for humans and a desirable element of travel. Scenario two envisages the future of sport hunting, a practice that has roots to our earliest of ancestors, and how in $\mathbf{2 0 7 0}$ the sport could suffice in a manner that future hunters pay private nature reserve companies to clone animals for sport hunting purposes. Scenario three examines the potential for establishing safari-zoo environments where humans will clone animals that have long been extinct as an attempt to preserve and re-establish past insufficiencies, a sense of responsibility to our world. Conservation and education will be at the forefront of safari-zoo tourism attractions as will the inevitability of displaying the latest in human capabilities. Significantly, tourism and the tourist have been considered, because the desire of future tourists to engage with such experiences is nothing new, eating meat and fish in restaurants, hunting animals for sport and leisure, and witnessing animals in safaris and zoos is a past time activity that was established before we were on this planets and has every opportunity to continue in the future. The only limitation to all of these is the depletion of species that is central to all three tourism based activates and scenarios. Therefore, if cloning offers an opportunity for industries, organisations and tourism and leisure experiences to continue, and the demand is present, the prospect for businesses to take advantage of such opportunities is evident. The ethical debates continue to be a draw for activist and anti-cloning groups, but what if technology limits the pain and suffering of animals being cloned in the future, this will could end a significant ethic side of the debate, consequentialist issues surround the nature of cloning. As for the human potential of cloning as a result of animal cloning progress, well the movements have already begun in this field, as well as other genetically modified and technologically advanced procedures that can be seen as humans 'playing god'. As for the deontological debates, in the future these will arguably continue to exist. As long as Homo Sapiens embrace different beliefs, attitudes, and moral codes, be it based on religious foundations or more secularist grounds, then there is every chance that different practices in cloning will exist throughout our global community as it does today.

The aim of this study and the focus of the scenarios is to continue providing interesting research (Ramirez, 2015). Research that aims to engage audiences, to be debated and contested. Clearly cloning presents a contested level of opinions and feelings, much 
depending on the background of any individual. But the reality, cloning exists and shows little signs of ceasing. In fact, quite the opposite, as the future of cloning and the interest and attention it attracts looks likely to increase within the scientific community and beyond. Thus, this paper offers a somewhat provocative account of potential future tourism industries and how they could benefit from animal cloning to meet the demands of future tourism and leisure consumers - with the intention of generating discussion and debate. Future research should continue to explore the potential role of cloning in tourism, exploring alternative scenarios in which cloning and tourism could be cohesively allied. In this paper, three different scenarios have been expressed based on past and present human activates. There is every possibility that if cloning is to persist in human societies, then there will be many different uses across societies, countries, and continents. Because in all likelihood, in 2070 , there will continue to be a diverse mixture of attitudes, beliefs and moral outlooks towards the practices in which cloning could take place, be its of knowledge enhancement, for medicinal benefits, or as explored in this study, for tourism and leisure purposes.

"Just because your way is different, doesn't mean my way is wrong." 


\section{References}

AFP (2016). The Dolly legacy: Are you eating cloned meat? Available at:

http://www.news.com.au/technology/science/animals/the-dolly-legacy-are-you-eating-clonedmeat/news-story/957f93ed4a9f466c295069c95c60db52. Accessed on: 30/03/2017.

Anonymous (2002). Reviving the Tasmanian tiger. Science 296: 1797

Argus, C. (2017). When game parks become killing fields. Available at: http://www.pressreader.com/south-africa/cape-argus/20170314/281840053473539.

Accessed on: 15/05/2017.

Bale, J. (1989). Sports Geography. London: E. and FN Spon.

Barrett, M. (2016). Living Planet Report 2016, Available at:

https://www.wwf.org.uk/updates/landmark-report-shows-global-wildlife-populations-coursedecline-67-cent-2020. Accessed on: 30/03/2017.

Bartunek, J. M., Rynes, S. L., \& Ireland, R. D. (2006). What makes management research interesting, and why does it matter? Academy of management editors' forum. Academy of Management Journal, 46(1), 9-15.

Baulch, B. (2013). Hunt with a rocket launcher, you know, because you have terrible aim. Available at: https://www.thrillist.com/travel/nation/fire-exotic-weapons-at-shooting-range-inphnom-penh-cambodia. Accessed on: 15/05/2017.

BBC (2013). Findus beef lasagne contained up to $100 \%$ horsemeat, FSA says, Available at: http://www.bbc.co.uk/news/uk-21375594. Accessed on: 16/05/2017.

Becken S. (2013) Shapers and shifters for the future of travel and tourism. In Leigh, J., Webster, C., \& Ivanov, S. (eds) Future Tourism: Political, social and economic challenges. Routledge Advances in Tourism, Oxon: 80-91.

Bethge, P. (2012). Scientists Hope Cloning Will Save Endangered Animals. Available at: http://www.spiegel.de/international/world/scientists-hope-interspecies-cloning-will-saveendangered-animals-a-865932.html. Accessed on: 16/05/2017.

Bienkov, A. (2017). Theresa May says she backs fox hunting because other methods of killing foxes are 'cruel', Available at: http://uk.businessinsider.com/theresa-may-backs-foxhunting-because-other-methods-are-cruel-2017-5. Accessed on: 16/05/2017.

Brulliard, K. (2016). Zoos will 'look and act radically different in 20 years'. Available at: https://www.washingtonpost.com/news/animalia/wp/2016/07/05/zoos-will-look-and-actradically-different-in-20-years/?utm_term=.d8b6d64f69de. Accessed on: 11/05/2017.

Bunn, D. W. \& Salo, A. A. (1993). Forecasting with scenarios. European Journal of Operational Research, 68, 291-303.

Burgess, M. (2017). Where are the human clones? 20 years since Dolly was unveiled we look at the future of cloning Cloning technology is mostly used for agriculture, so where will the technology go next? Available at: http://www.wired.co.uk/article/human-cloningtechnology-dolly-sheep. Accessed on: 15/05/2017.

Cabanac, M. (2002). "What is emotion?" Behavioural Processes 60(2): 69-83. 
Callaway, E. (2012). Scientists are preparing ambitious plans to resurrect long-dead animals from passenger pigeons to woolly mammoths. But can they succeed? Available at:

http://www.bbc.com/future/story/20120229-can-we-resurrect-extinct-species. Accessed on: 09/05/2017

Carey-Stanford, B. (2015). Why ocean animals are in deep trouble. Available at: http://www.futurity.org/ocean-extinction-839822/. Accessed on: 30/03/2017. Carrington, D. (2014). Earth has lost half of its wildlife in the past 40 years, says WWF. Available at: https://www.theguardian.com/environment/2014/sep/29/earth-lost-50-wildlife-in40-years-wwf. Accessed on: 30/03/2017.

Darimont, C. T., Fox, C. H., Bryan, H. M. \& Reimchen, T. E. (2015). The unique ecology of human predators, Science, 394(6250), 858-860.

Datta, L. (1994). Paradigm wars: A basis for peaceful co-existence and beyond. In C. S. Reichardt \& S. F. Rallis (Ed.), The Qualitative-Quantitative Debate: New Perspectives. San Francisco: Jossey-Bass. p. 53-70.

DeFazio, F. (2017). Are We Eating Cloned Meat? Available at:

https://www.scientificamerican.com/article/are-we-eating-cloned-meat/. Accessed on: 30/03/2017.

Ducot, C. \& Lubben, G. J. (1980). A typology for scenarios. Futures 12(1), 51-57.

Ecoist (2017). 12 Endangered Animals That People Still Eat. Available at: http://webecoist.momtastic.com/2009/04/09/12-endangered-animals-that-people-still-eat/. Accessed on: 30/03/2017.

European Tourism Futures Institute (2012). The Future of Zoos. Stenden, Available at: http://www.etfi.nl/en/projects/zoo-future. Accessed on: 16/05/2017.

Fa, J. E., Peres, C. A. \& Meeuwig, J. (2002). Bushmeat Exploitation in Tropical Forests: an Intercontinental Comparison. Conservation Biology, 16(1), 232-237.

Fahey, L. R. and Randall, R. (1998). What is scenario learning. In Fahey, L. and Randall, R. (eds) Learning from the Future: Competitive Foresight Scenarios, New York, Wiley: pp.3-43.

Fiester, A. (2005). Ethical issues in animal cloning. Perspectives in Biology and Medicine, 48(3): 328-343.

Flowerhill (2017). Come Fox Hunting in Ireland. Available at: http://www.flowerhill.net/Foxhunting_Ireland.htm. Accessed on: 15/05/2017.

Gaarder (2016). The Ethics of the Future. Available at: http://www.huffingtonpost.com/josteingaarder/ethics-future_b_8576266.html. Accessed on: 20/08/2017.

Gaudzinski, S. (2004). Subsistence patterns of Early Pleistocene hominids in the Levant Taphonomic evidence from the 'Ubeidiya Formation (Israel). Journal of Archaeological Science. 3. 65-75.

Goode, E. (2015). A Shifting Approach to Saving Endangered Species. Available at: https://www.nytimes.com/2015/10/06/science/a-shifting-approach-to-saving-endangeredspecies.html?mcubz=0. Accessed on: 20/08/2017.

Hinch, T. \& Higham, J. (2011). Sport Tourism Development (Second Edition). Bristol, 
Channel View Publications.

Humane Society (2016). Trophy Hunting by the Numbers: the united states' role in global trophy hunting. Available at:

http://www.hsi.org/assets/pdfs/report_trophy_hunting_by_the.pdf. Accessed on: 15/05/2017.

Hartley, S. (2009), "BT Futurologist: We're Living in Sc-Fi”, Available at:

https://www.theguardian.com/media/pda/2009/jul/23/bt-futurologist-science-fiction. Accessed on: $12 / 05 / 2017$.

Hancock, D. (2001). A different nature: the paradoxical world of zoos and their uncertain future. University of California Press: Berkeley and Los Angeles, California, U.S.A.

Heijden Van der., Bradfield, R., Burt, G., Cairns, G., \& Wright, G. (2002). The sixth sense: accelerating organizational learning with scenarios. Chichester, UK: Wiley.

Holt, W., Pickard, A. R. \& Prather, R. S. (2004). Wildlife conservation and reproductive cloning, Reproduction, 127: 317-324.

Ingham, L. (2015). The allure of travel used to be the new, but as climate change continues to alter the environment, focus is shifting towards the nearly-extinct. We investigate the rise in extinction tourism, Available at: http://factor-tech.com/space/26349-a-lunar-station-is-thenext-logical-step-in-space-development/. Accessed on: 16/05/2017.

Jabr, F. (2013). Will Cloning Ever Save Endangered Animals? Available at: https://www.scientificamerican.com/article/cloning-endangered-animals/. Accessed on: 30/03/2017.

Jenkins, C. N., Pimm, S. L. \& Joppa, L. N. (2013). Global patterns of terrestrial vertebrate diversity and conservation, PANS, 110(28), 2602-2610.

Jones, I. \& Green, B. (2006). Serious Leisure, Social Identity and Sport Tourism. In Gibson, H. (eds). Sport Tourism Concepts and Theories, Sport in the Global Society series, Oxon, Routledge: 32-49.

Johnson, R. B. \& Onwuegbuzie, A. J. (2004). Mixed methods research: a research paradigm whose time has come. Educational Researcher, 33(7), 14-26.

Johnson, R. B., Onwuegbuzie, A. J. \& Turner, L. A. (2007). Toward a definition of mixed methods research. Journal of Mixed Methods Research, 1(2), 112-133.

Jungermann, H. (1985). Inferential processes in the construction of scenarios. Journal of Forecasting, 4, 321-327.

Kivela, J., \& Crotts, J. (2005). Gastronomy and tourism: A meaningful travel market segment. Journal of Culinary Science \& Technology, 4(2/3), 39-55.

Learn Genetics (2017). The History of Cloning. Available at: http://learn.genetics.utah.edu/content/cloning/clonezone/. Accessed on: 29/03/2017.

Lee, K. (2001). Can cloning save endangered species? Current Biology, 11(7). R246-R246.

Lee, M. (2012). Knowing our future: The startling case for futurology. Infinite Ideas Limited, Oxford. 
Leigh, J. (2013) 'Peak Oil' confronts society and tourism: A futuristic view. In Leigh, J., Webster, C., \& Ivanov, S. (eds) Future Tourism: Political, social and economic challenges. Routledge Advances in Tourism, Oxon: 2-20.

Lepore, S. M. (2015). Chinese cloning firm "won't make Frankensteins" with humans. Available at: http://www.nydailynews.com/news/world/cloning-firm-no-plans-clone-humansarticle-1.2479074. Accessed on: 30/03/2017.

Lindgren, M., \& Bandhold, H. (2009). Scenario planning: the link between future and strategy. New York: Palgrave Macmillan.

Living Planet Report (2016). Living Planet Report 2016: Risk and resilience in a new era. Available at:

http://www.wwf.org.uk/sites/default/files/201610/LPR_2016_full\%20report_spread\%20low\%2 Ores.pdf. Accessed on: 20/01/2017.

Maxcy, S. J, (2003) Pragmatic threads in mixed methods research in the social sciences: The search for multiple modes of inquiry and the end of philosophy of formalism. In Tashakkori, A., \& Teddlie, C. (eds) Handbook of mixed methods in social behaviour research, Sage Publications, London. p. 51-90

Meek, J. (2002). Scientists pledge to clone extinct Tasmanian tiger. Available at: https://www.theguardian.com/world/2002/may/29/animalwelfare.highereducation. Accessed on: 09/05/2017.

Mendiratte, A. (2011). Come closer: How tourism is shaping the future of nations. Myriad Publications International/ South Africa.

Merchant, B. (2015). The last time oceans go this acidic this fast, $96 \%$ of marine life went extinct. Available at: http://motherboard.vice.com/read/the-last-time-our-oceans-got-thisacidic-it-drove-earths-greatest-extinction. Accessed on: 20/01/2017.

Milman, O. (2016). Sanctuaries or showbiz: what's the future of zoos? Available at: https://www.theguardian.com/world/2016/mar/23/sanctuaries-or-showbiz-zoos-struggle-tobalance-conservation-and-entertainment. Accessed on: 12/05/2017.

Milner-Gulland, E. J. \& Bennett, E. L. (2003). Wild meat: the bigger picture. Trends in Ecology and Evolution, 18(7), 351-357.

Misra R. (2014). Why Science Fiction Likes To Look 50 Years Into The Future, Available at: http://io9.gizmodo.com/why-science-fiction-likes-to-look-50-years-into-the-fut-1655665596. Accessed on: 12/05/2017.

Narula, S. K. (2014). Sushinomics: How Bluefin Tuna Became a Million-Dollar Fish Once used for cat food, the endangered fish is now one of the most prized delicacies in the world. Available at: https://www.theatlantic.com/international/archive/2014/01/sushinomics-howbluefin-tuna-became-a-million-dollar-fish/282826/. Accessed on: 16/05/2017.

National Human Genome Research Institute (2017). Available at: https://www.genome.gov/25020028/cloning-fact-sheet/. Accessed on: 29/03/2017.

Nelson, B. (2010). 15 endangered species that are still on the menu. Available at: http://www.mnn.com/earth-matters/animals/photos/15-endangered-species-that-are-still-onthe-menu/delicacy. Accessed on: 30/03/2017. 
Norris, K. (2016). Living Planet Report 2016, Available at:

https://www.wwf.org.uk/updates/landmark-report-shows-global-wildlife-populations-coursedecline-67-cent-2020. Accessed on: 30/03/2017.

Okumus, B., Okumus, F., \& McKercher, B. (2007). Incorporating local and international cuisines in the marketing of tourism destinations: The cases of Hong Kong and Turkey. Tourism Management, 28, 253-261.

Ormandy, E. H., Dale, J., \& Griffin, G. (2011). Genetic engineering of animals: Ethical issues, including welfare concerns. The Canadian Veterinary Journal, 52(5): 544-550.

Oxford Dictionary (2017). Definition of desire. Available at: https://en.oxforddictionaries.com/definition/desire. Accessed on: 21/08/2017.

Pegoda, A. J. (2015). Priorities: Money and Poverty, Michelle Obama, Food Deserts, and Geography. Available at: https://andrewpegoda.com/2015/05/03/priorities-money-andpoverty-michelle-obama-food-deserts-and-geography/. Accessed on: 20/08/2017.

Peterson, G. D., Cumming, G. S., \& Carpenter, S. R. (2003). Scenario planning: a toll for conservation in an uncertain world. Conservation Biology, 17(2), 358-366

Rabinovich, R., Gaudzinski-Windheuser, S., \& Goren-Inbar, N. (2008). Systematic butchering of fallow deer (Dama) at the early Middle Pleistocene Acheulian site of Gesher Benot Ya'aqov (Israel), Journal of Human Evolution. 54. 134-149.

Rallis, S. F. \& Rossman, G. B. (2003). Mixed methods in evaluation contexts: a pragmatic framework. In A. Tashakkori \& C. Teddlie (Eds), Handbook of Mixed Methods in Social and Behavioral Research. Thousand Oaks, CA.: Sage.

Ramirez, R., Mukherjee, M., Vezzoli, S., \& Kramer, A. M. (2015). Scenarios as a scholarly methodology to produce "interesting research". Futures, 71, 70-87

Regan, T. (1983). The case for animal rights. Berkeley: Univ. of California Press.

Ripple, W. J., Abernethy, K., Betts, M. G., Chapron, G., Dirzo, R., Galetti, M., Levi, T., Lindsey, P. L., Macdonald, D. W., Machovina, M., Newsome, T. M., Peres, C. A., Wallach, A. D., Wolf, C., and Young, H. (2016). Bushmeat hunting and extinction risk to the world's mammals, Royal Society 3, 1-16.

Robinson, R. N. S., \& Getz, D. (2016). Food enthusiasts and tourism: Exploring food involvement dimensions. Journal of Hospitality \& Tourism Research, 40(4): 432-455.

Rollin, B. (1981). Animals rights and human morality. Buffalo, NY: Prometheus Books.

Rooney, J. F. \& Pillsbury, R. (1992). Sports regions of America. American Demographics, 14(10), 1-10.

San Diego Zoo Institute for Conservation Research (2017). Mission and Purpose. Available at: http://institute.sandiegozoo.org/who-we-are/mission-purpose. Accessed on: 09/05/2017.

SCI (2016). Hunter Advocacy. Available at: https://www.safariclub.org/what-we-do/freedomto-hunt. Accessed on: 20/01/2017.

SCI (2017). World Hunting Awards, Available at: https://www.safariclub.org/what-wedo/record-book/world-hunting-awards. Accessed on: 15/05/2017. 
Shockman, E. (2016). Where is modern cloning, 20 years after Dolly? Available at: https://www.pri.org/stories/2016-08-14/where-modern-cloning-20-years-after-dolly. Accessed on: 15/05/2017.

Sinclair, K. D., Corr, S. A., Gutierrez, C. G., Fisher, P. A., Lee, J.-H., Rathbone, A. J., Choi, I., Campbell, K. H. S. \& Gardner, D. S. (2016). Healthy ageing of cloned sheep. Nature Communications, 7. 1-10.

Singer, P. (1975). Animal liberation: A new ethic for our treatment of animals. New York: Avon.

Tashakkori, A. \& Creswell, J. W. (2007). Exploring the nature of research questions in mixed methods research. Journal of Mixed Methods Research, 1(3), 207-11.

Tashakkori, A. \& Teddlie, C. (1998). Mixed Methodology: Combining Qualitative and Quantitative Approaches. Thousand Oaks, CA.: Sage.

Tashakkori, A. \& Teddlie, C. (Eds.) (2003). Handbook of Mixed Methods in Social and Behavioral Research. Thousand Oaks, CA.: Sage.

The IUCN Red List of Threatened Species (2017). About. Available at: http://www.iucnredlist.org/. Accessed on: 12/05/2017.

Thompson, A. E. (1979). Understanding Futurology: An introduction to futures study. David \& Charles Publishing, Devon.

Tourism Futures (2017). Organic label: no cloned animals, period. Available at: http://www.tourism-futures.org/content/view/1108/226/. Accessed on: 30/03/2017.

Vannewkirk, G. (2016). Artificial Cloning: Unnatural \& Inhumane, or the Savior of Endangered Species? Available at: http://earthtalk.org/artificial-cloning-endangered-species/. Accessed on: 08/05/2017.

Walton, J. (2008). Scanning Beyond the horizon: Exploring the ontological and epistemological basis for scenario planning. Advances in Developing Human Resources, 10 (2), 61-63.

Wong, K. (2014). How hunting made us. Scientific American, 310(4)

Worland, J. (2017). The Future of Zoos. Time, 189 (7/8), p54-61.

Yeoman, I. (2008) Tomorrow's Tourist: Scenarios \& Trends. Oxford, Elsevier.

Yeoman, I. (2012), 2050: Tomorrows Tourism, Channel View Publications, Bristol.

Yeoman, I., McMahon-Beattie, U., Fields, K., Albrecht, J. N., \& Meethan, K. (2015). The Future of Food Tourism: Foodies, Experiences, Exclusivity, Visions and Political Capital. Channel View Publications, Bristol.

Yinger, M. (1960). Contraculture and subculture, American Sociological Review, 25(5), 625635. 